\title{
متطلبات التنمية المهنية للمشرفات التربويات برياض الأطفال في ضو ء مجتمعات التعلم المهنية
}

إعداد

الباحثة / حبيبة محلد صابر بركات إد

\section{إشراف}

أ.د// السيد عبد القادر شريف

أستاذ أصول تربية الطقل

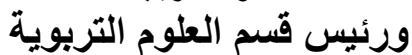

كلية التربية للطفولة المبكرة - جامعة القاهرة
أ.د/ منى محمد علي جاد

أستاذ تربية الطقل بقسم العلوم التربوية

عميد كلية التربية للطفولة المبكرة الأسبق المبلى كلية التربية للطفولة المبكرة - جامعة القاهرة

أ.م.د. سماح عبد القتاح عحمامرزوق

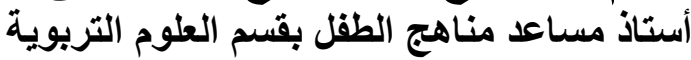

كلية التربية للطفولة المكبرة - جامعة القاهرة

مقدمة البحث:

تعد مجتمعات التعلم المهنية اسلوب منهجى لتحسين اداء التعليم والتعلم ،حيث انه من خلال تصميم

وبناءمجتمعات التعلم المهنية فان ذلك يؤدى الى التغلب على ثقافة الانعز ال وتجزئة عمل المشرفات ،كما تظهر الدر اسات ان بناء وتطوير مجتمعات تعلم مهنية قوية ترتكز على تحسين عمليتى التعليم و التعلم ،مما

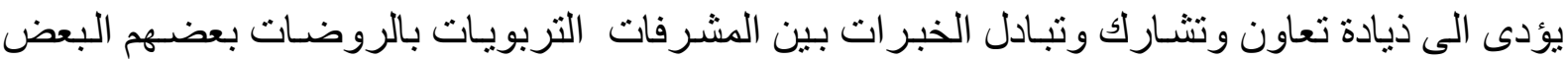

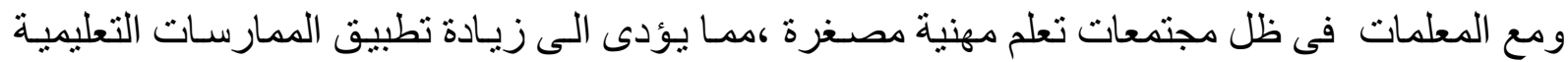

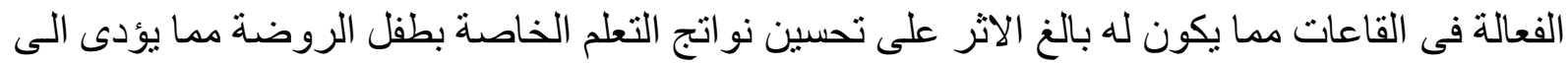
جودة التعلم برياض الاطفال .

ويمثل الاشر اف التربوي احد الأركان الأساسية في المنظومة التربوية، يؤدى دور ا رئيسيا في دعم

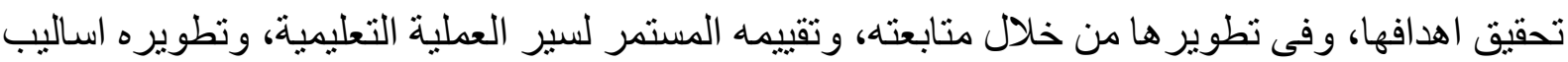

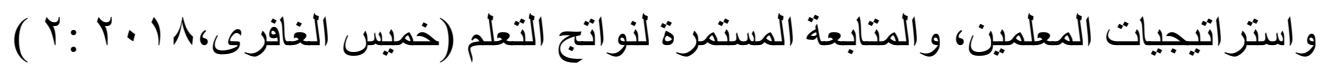

وتعتبر المشرفات التربويات بالروضة بمثابة الموجة الفنى المقيم ،حيث تقوم بالاشر اف و المتابعة

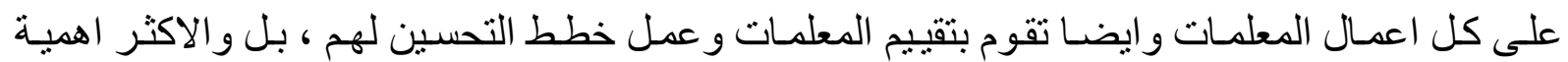
ملاحظة مدى تقدم الاطفال وتحقيق مطالب النمو لهم بل وقياس مدى تحقق نواتج التعلم الموضـوعة مسبقا 
وفى ظل التقدم الموجود و الثورة المعرفية و التقدم المعرفى التكنولوجى الذى انعكس على النظم

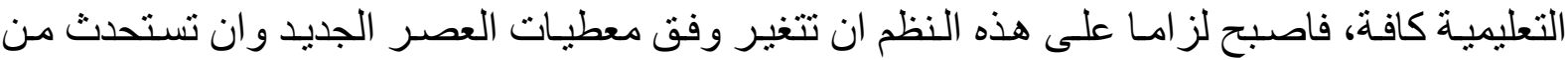
الاجر اءات الداخلية مما يؤدى الى التطوير المستمر فى كافـة عناصـر المؤسسـة التعليمية (تحاين موسىى،

وكان لز اما على المشرفة التربوية ان تمتلك مجمو عة من الادوات و المتطلبـات تجعلها قادرة على توجيه المعلمات وتحقيق رؤية ورسالة الروضة بل والاهم الاهتمـام بالطفل وتقييمـه وان تغيير من ادائها

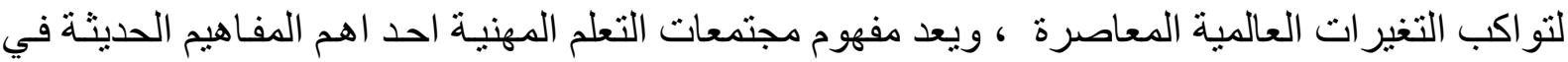
تطوير الاداء المدرسي ، واحد اليات التطوير المخطط لتحويل المدارس الى مجتمعات تعلم مهنيـة، ليكون

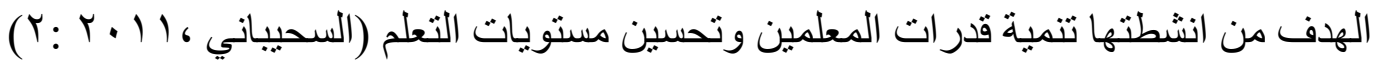
و نظر اً لأهمية مهام المشرفات تبعاً للعديد من المتغير ات منها التنميـة المهنية للمعلمات والإشـر اف

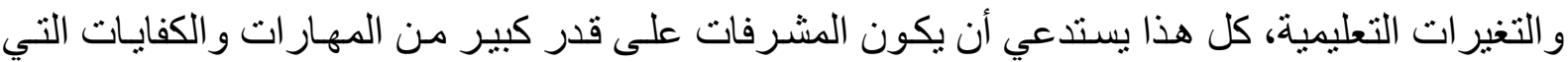

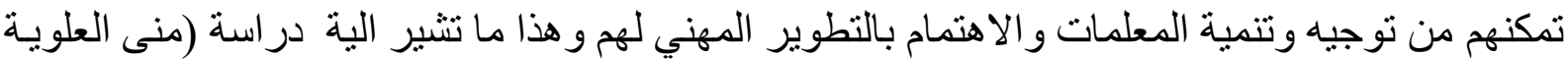

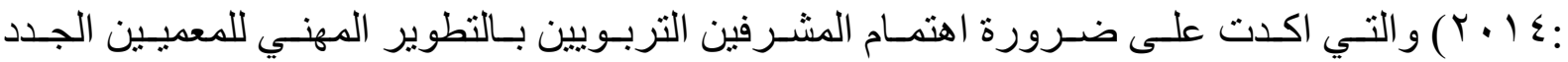
والمعلمين الذين لايهم قصور في ادائهم التدريسي.

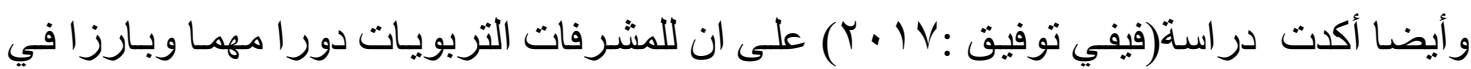
تغيير ثقافة التعليم ، فهم من بساهموا في بناء ثقافة التعليم وتحسين اداء المعلمات و المتعلمين .

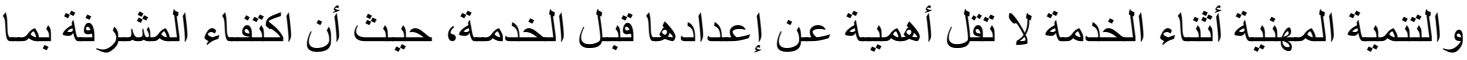
حصلته في سنوات إعدادها قبل الخدمة (مرحلة البكالوريوس) أو العمل بالإشـر اف في الروضهات إنهات ليكون

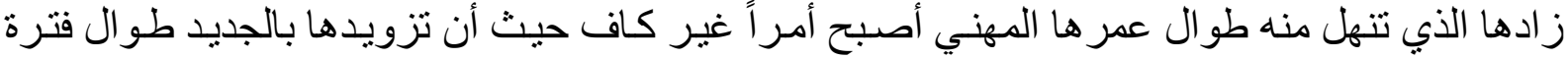

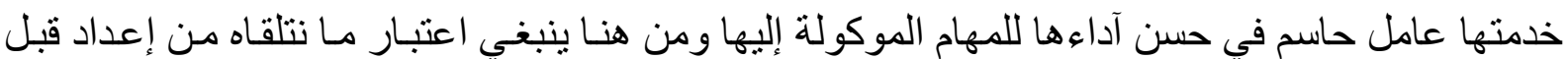

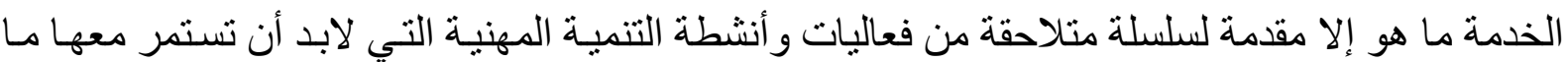
دامت الحياة ومادام هنالك معارف هو وتقنيات جديدة.

مشكلة البحث وتساؤلاته:

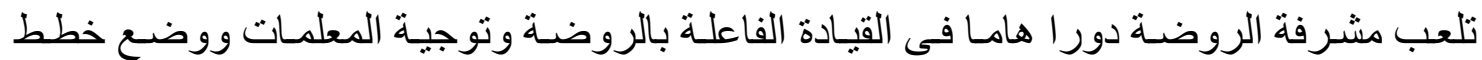

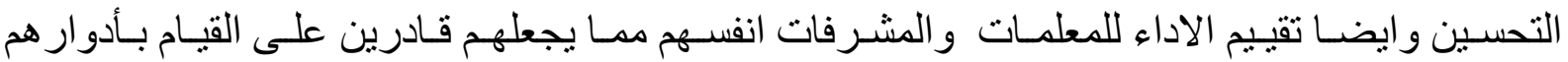

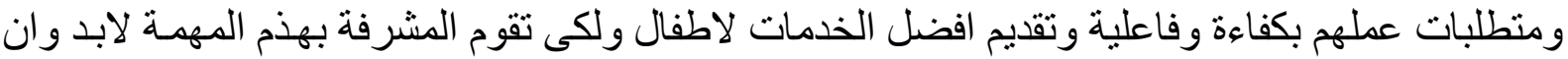
تمتلك من الكفايات و المهار ات و المعارف ما يجعلها قادرة على ذللك .

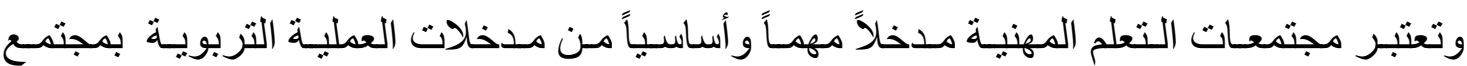

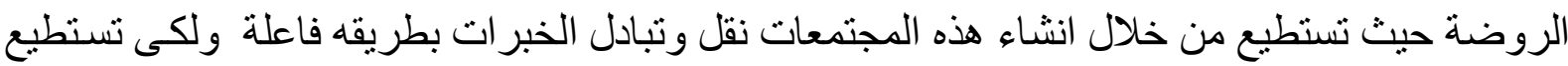

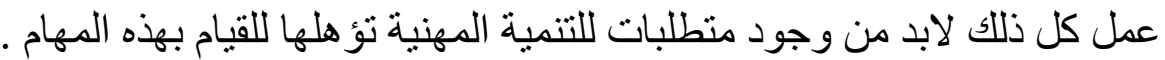

هذا وقد تم ملاحظة مشكلة البحث من خـلال الاحتكاك المباشـر بالمشرفات في الروضـات من فن خلال عمل الباحثة كموجة فنى و لاحظت الباحثة قصور لدى المشرفات في التنمية المهنية ومجتمعاتها 
وتفعيلها مـع المعلمـات وتحديد الأحتياجـات التدريبيـة لهم ، وتدريبهم على كل المستجدات التربويـة مدـا

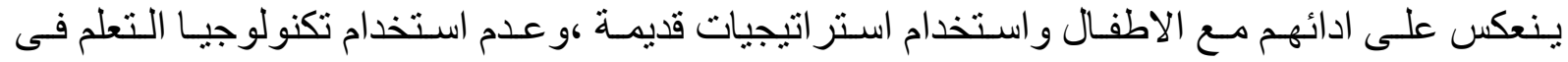

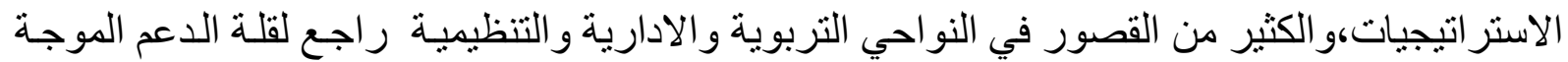

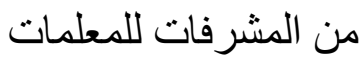

و ايضـا وجود قلـة فى الدر اسـات التـى إجريـت على متطلبـات المهنيـة لمشـرفات ريـاض الأطفـال

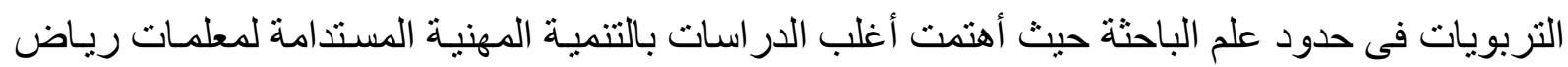
الأطفال

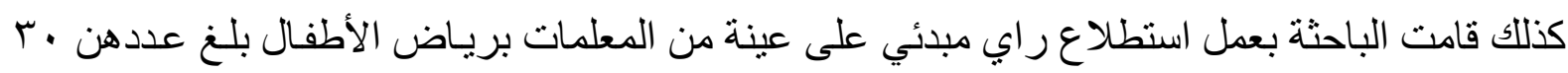

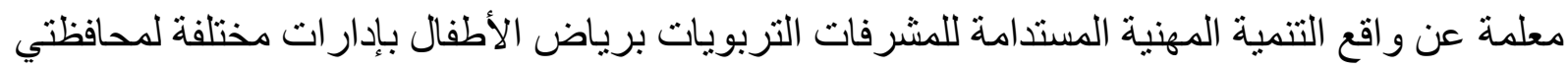

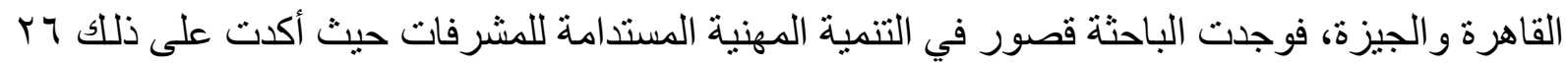

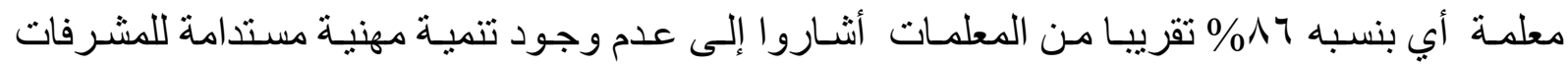
برياض الأطفال، ووجود قصور في تدريباتهم على الاساليب الحديثة في التعلم ،مما ينعكس على الاطى الطفال

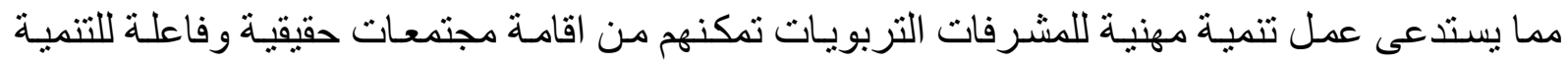

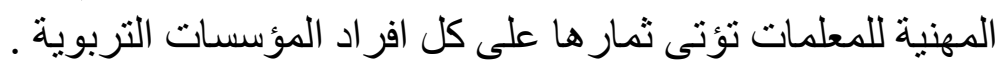
ومن هنا يحاول البحث الحالى الإجابة عن السؤال الرئيسى التالى على الثئي

مـا متطلبـات التتمية المهنيـة للمشرفات التربويـات بريـاض الأطفـال في ضوء مجتمعات التعلم المهنية؟ مئب ويتفرع عن السؤال الرئيسى الأسئلة التالية:

ا ـ ما واقع التمية المهنية المستدامة لمشرفات رياض الأطفال ؟

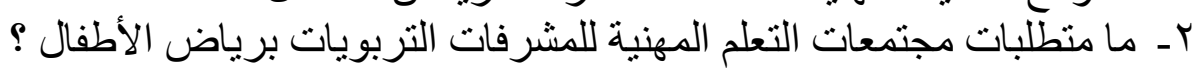

أهمية البحث:

أولا: الأهمية النظرية :

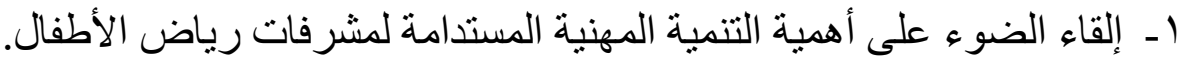

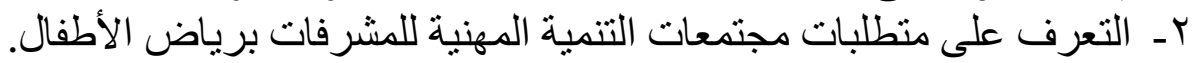
r- القاء الضوء على اهمية واستمر ارية بر امج تدريب المشرفات لانعكاسها على كل العملية التعليمية

\section{ثانيا: الأهمية التطبيقية:}

ا ـ تدريب المشرفات وتطوير مهارتهن للوصول بهن الى مستوى الاداء الفعال للتعامل مع المعلمات

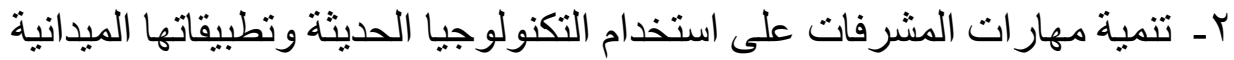
r- التعرف على الاتجاهات الحديثة في مجال التنمية المهنية لمشرفات رياض التهات الاطفال وتوظيفها من خلال مجتمعات التعلم المهنية التهات 


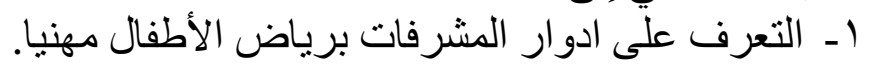

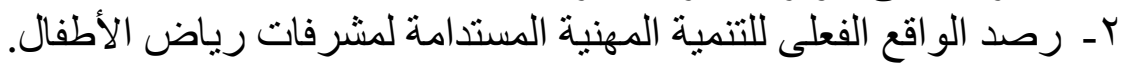

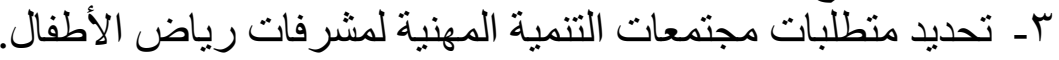

منهج البحث:

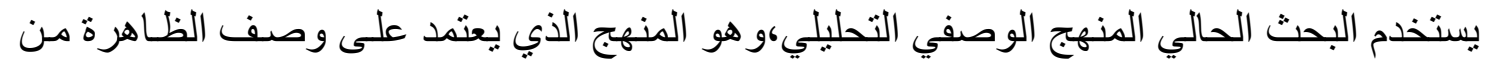

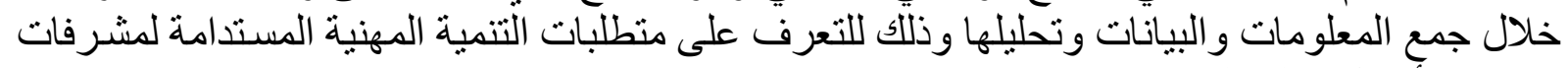

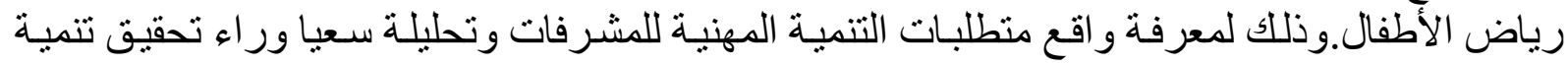
مهنية للمشرفات تؤثر ايجابيا على بيئة التعلم أدوات البحث:

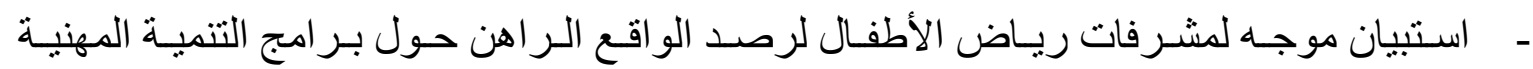

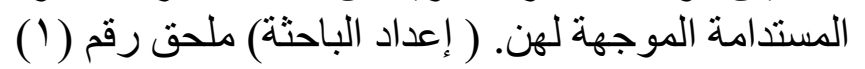

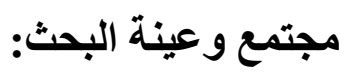

يبلغ إجمالى عدد المشرفات التربويات فى إدارة 7 اكتوبر التعليمية ( ـ 1 مشرفة تربوية ) وتكونت

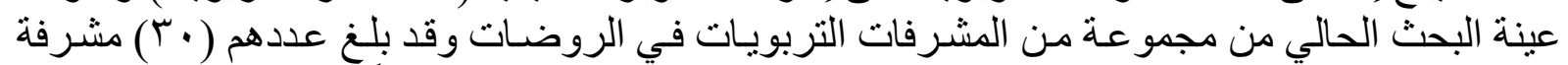

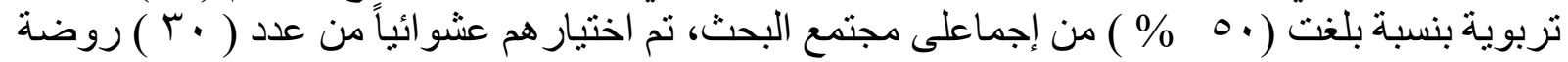
بادارة 7 اكتوبر التعليمية

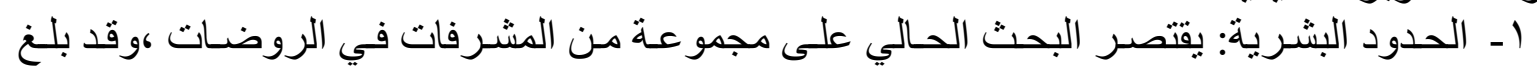

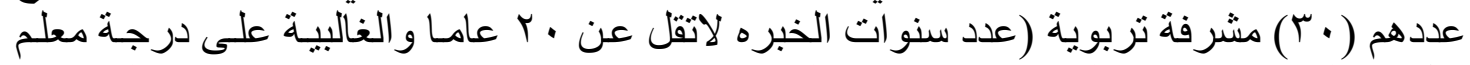

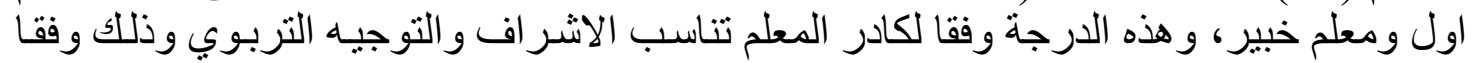
للخبرة و عدد السنو ات ات العمل).

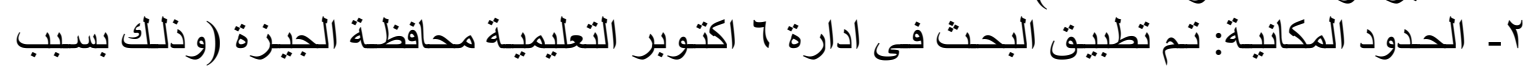

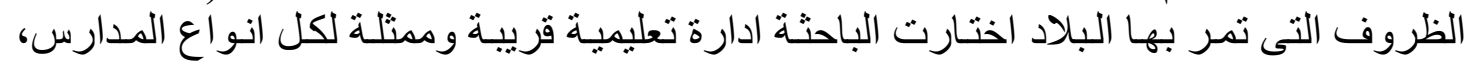

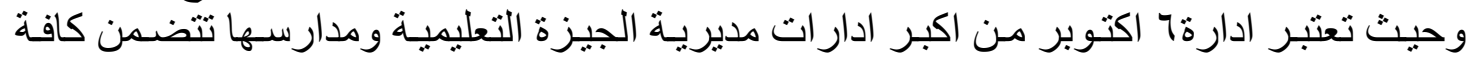

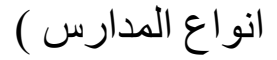

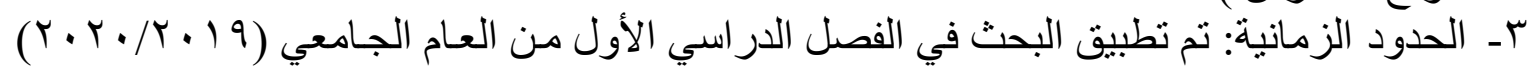

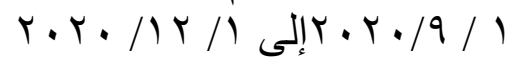

\section{مصطلحات البحث:}

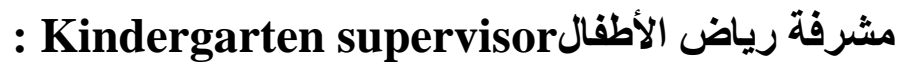

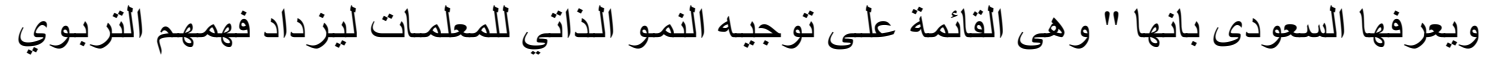

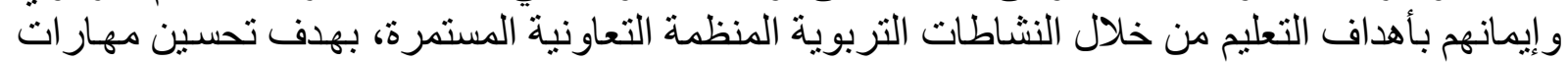

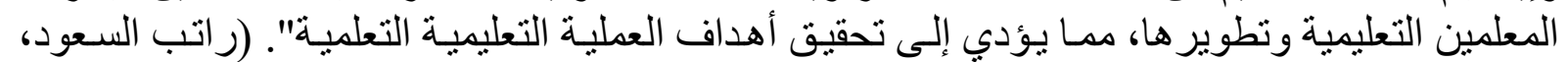




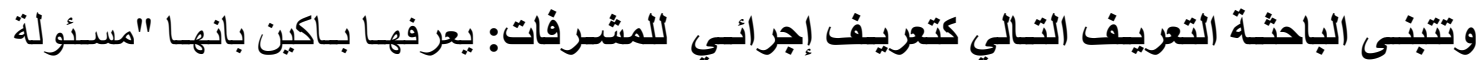

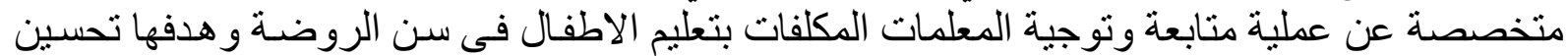
العملية التعليمية بصفة عامة (Bakan,2013:231).

\section{Sustainable Professional Development التنمية المهنية المستدامة تونة}

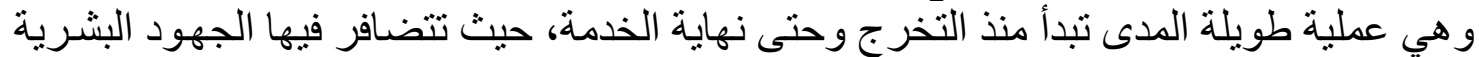

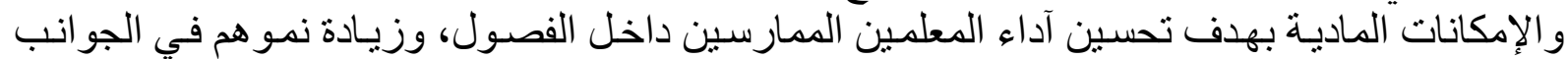
المعرفية والمهار ات و السلوكية. (Beverley Bell \& John,1996 p44)

\section{التعريف الإجرائي للتنمية المهنية المستدامة :}

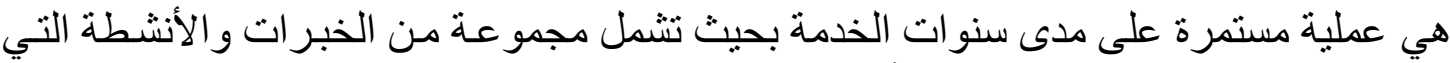
تمكن المعلمين من تحسين كفاءتهم المهنية وتـأهيلهم لمو اجهة مـا يستحدث من تطور ات تربويـة و عمليـة، وذذلك من خلال التخطيط العلمي و التقويم المستمر

\section{professional Learning communities(PLCS ): مجتمعات التعلم المهنية}

عرفهـا موهـابير (Mohabir,2009:23) بانهـا تتظـيم لتعزيـز الـتعلم والتعـاون بـين المعلمـات

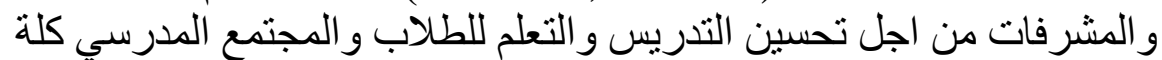

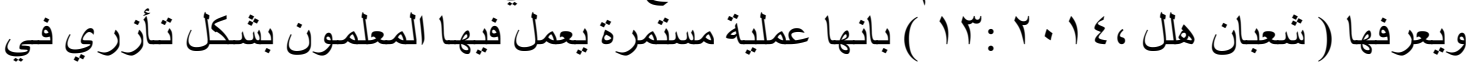

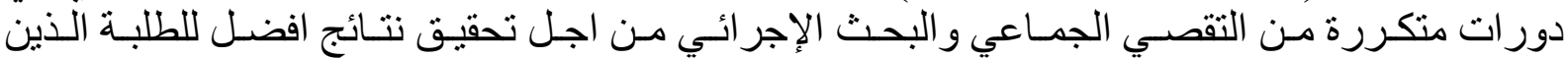
يخدمو هم.

التعريف الإجرائي لمجتمعات التعلم المهنية : هي عملية مستمرة على مدار سنوات الخبرة تقوم

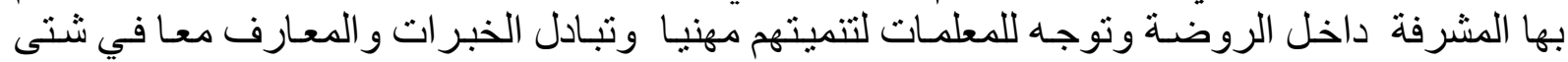
المعارف في جو من المودة والتعاون والاحتر ام حتى تتحقق التنميـة المهنيـة المستدامة وتكون الروضـات فاعلة الإطار النظري والدراسات السابقة:أولاً: التنمية المهنية المستدامة:

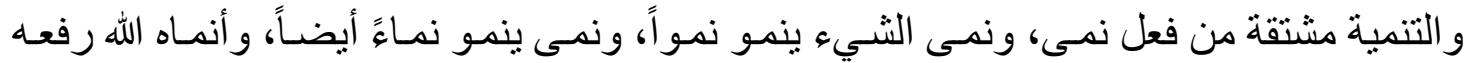

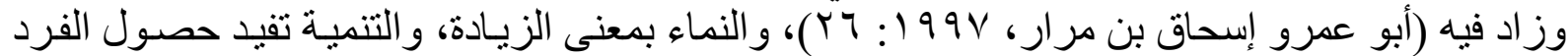

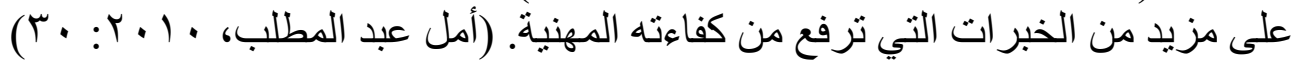
إن عملية التنمية المهنية عملية متغيرة ومتطورة، وكل فئة تتظر إلبها من جانب معين، ويشير إلى في زيادة مهارة أو تعديل سلوك أو طريقة بصورة تساعد على التعرف على المهام و الو اجبات بكفاءة عالية وسنعرض مجمو عة مختلفة من تعريفاتها:

يعرفها "سباركس ولوكس و هورسلي"(Sparks, D., \& Loucks-Horsley, S. 2013: 34)

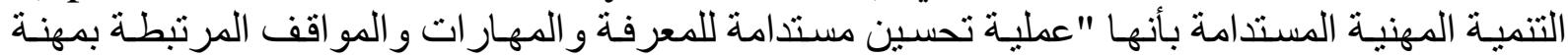
التوجيه التربوي". 


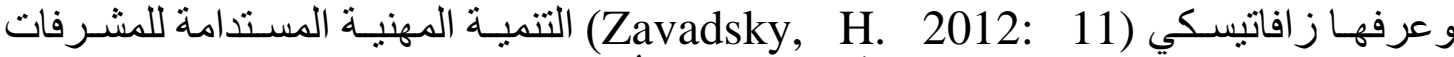

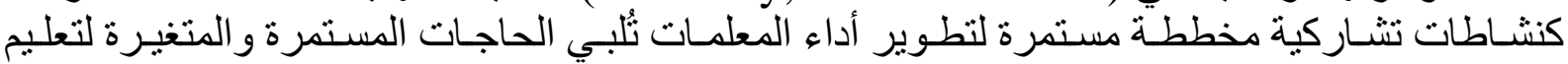
الأطفال وتحقيق الأهداف العامة لمرحلة رياض لمطن الأطفال

و هي أيضاً عملية تستهدف إضـافة معارف، وتنمية مهار ات، وقيم مهنية لدى المعلم لتحقيق تربيـة فاعلة وتعلم إيجابي لدى المتعلمين.

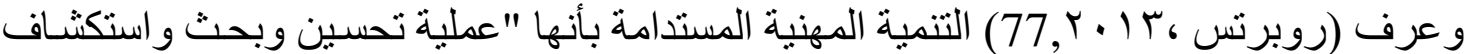

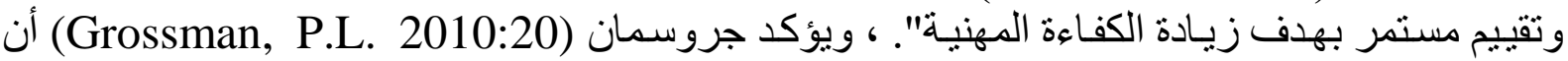
المحك الرئيسي للتنمية المهنية المستدامة يكمن في تحسن مستويات معرفة المعلمات بالأساليب التدريسية، وخصائص الأطفال الذين يتعاملن معهم، والقدرة على الاستفادة مما تعلموه.

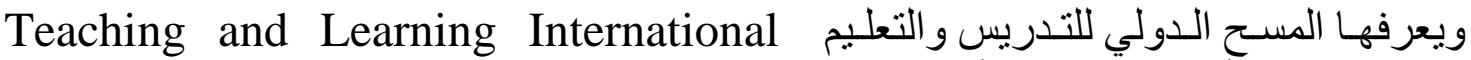

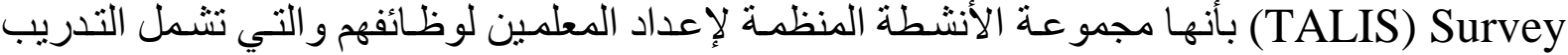

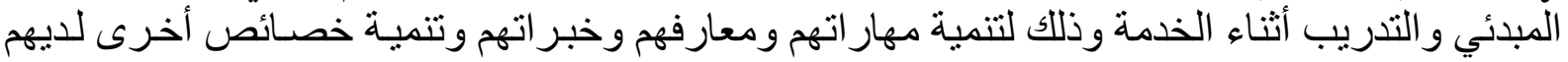
يحتاجونها كمعمين. (Education and Culture DG, \& OECD, 2013: 19)

و هنا نرى ان التنمية المهنية تعبر عن مجمو عة من الانشطة و التى تقدم بشكل منتظم ومستمر تذيد

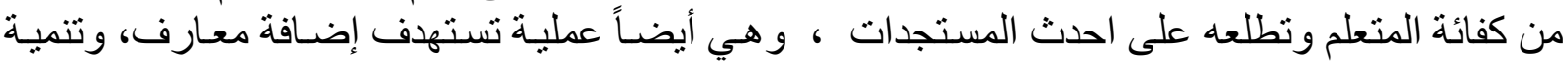
مهار ات، وقيم مهنية لدى المشرفة لتحقيق تربية فاعلة وتعلم إيجابي لدى المتعلمين.

و هذا يعني أنها عبـارة عن مجمو عـة من الفعاليات المستمرة التي يمكن أن تتم باستمر ار بحيث

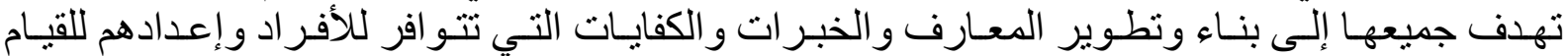
بالأدو ار المتغيرة التي تفرضها النظم و الظروف الخارجية و المجتمعية عليهم وتجعلهم مساريون لاتجاهات الحديثة .

النظريات الداعمة لمفهوم التنمية المهنية المستدامة للمشرفات التربويات برياض الأطفال: توجد العديد مـن النظريـات الداعمـة لمفهوم التنميـة المهنـة المستدامة للمشـرفات بريـاض الأطفـال،

\section{(1) النظريات السلوكية (ثورندايك، بافلوف، واطسون، سكينر):}

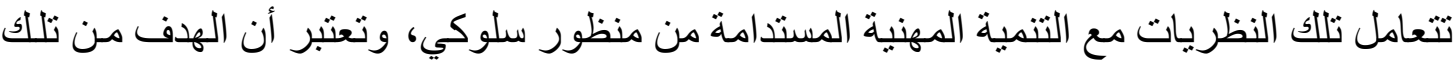

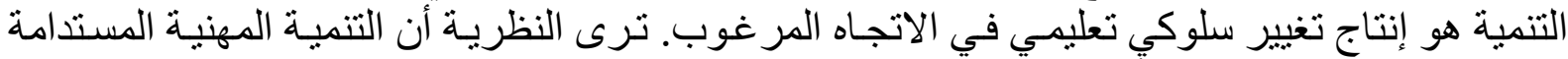

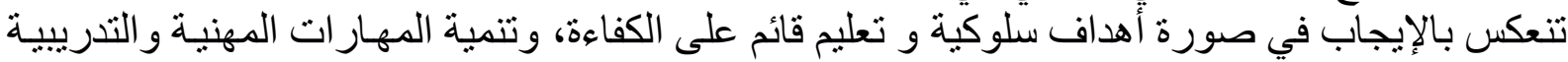
لكل من المشرفات و المعلمات.

\section{(Y) النظريات المعرفية (بياجيه، برونر، جاجني، أوزويل، ولوين):}

تؤسس تلك النظريـات إلى أن التنميـة المهنيـة المســدامة تحدث مـن خـلال عمليـة عقليـة داخليـة

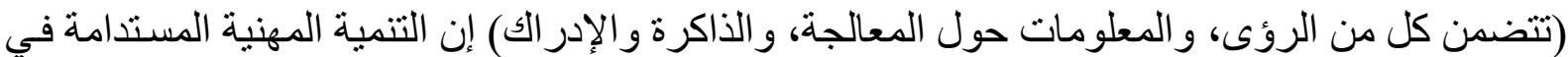
ظل تلك النظريـات تقوم على تطوير الكفـاءة و المهار ات لصـالح تعليم الأطفـال تنعكس التنميـة المهنيـة

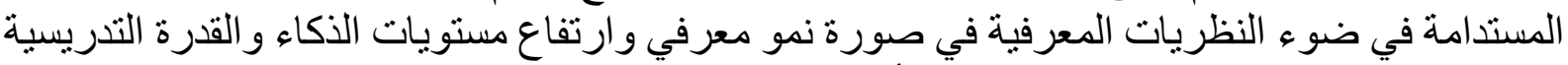
و الذاكرة من خلال الخبرة وتركز على تنمية أسلوب تعليم كيفية التعلم. 


\section{(") النظريات الإنسانية (ماسلو وروجرز):}

تفسر النظريات التنمية المهنية المستدامة كعمل شخصي نحو بلوغ القدرة القصـوى، يُعتبر هدف التنمية المهنية المستدامة للمشرفات و المعلمات وفقًا للنظرية هو تحقيق الذات والاستقلالية.

\section{؛ النظريات الاجتماعية (باندورا، سالومون، لافي، فينجر):}

تفسر النظريات أهداف التتمية المهنية المستدامة للمشرفات بنمو القدرة على التفاعل و الملاحظة

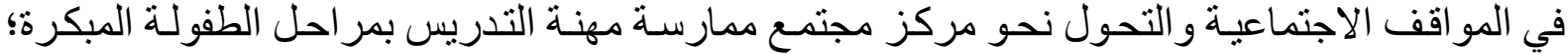
بالتالي تقوم التنمية المهنية المستدامة من خلال المشاركة التامة في مجتمعات الممارسة المهنية واستة واستخلال الموارد. (Rice, Rosalind, 2013: 250-265) .و هنا نرى اهتمام النظريات العلميـة المفسرة للتنميـة المهنية باعتبار ها اداة لتغير تقافة الفرد وتغيير قدر اته وتطوير مهار اته ومعارفة وخبر اته الى الافضل .

وأثـارت در اسـة كـلا مـن Anolan, Andrea; Morrissey, Anne-Marie; Beahan, ( Lord, Pippa; Atkinson, Mary; Mitchell, Holly (Jenni; Dumenden, Iris ,2011) (2011, إلى أهميه توجيه وتدريب المتخصصين في مجال الطفولة المبكرة، وخصوصـا المشرفات و در اسـة الأدلة البحثيـة حول فاعليـة استخدام التنمية المهنية المستدامة في تدريب المعلمـات و المشرفات،

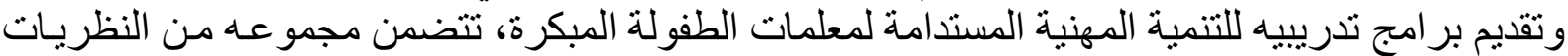

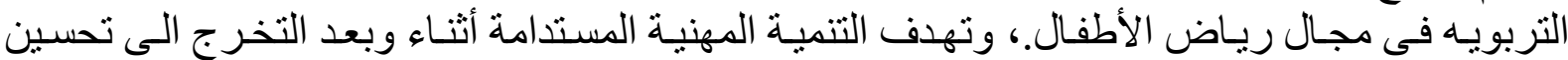

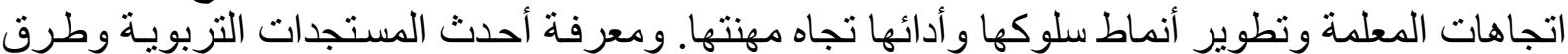

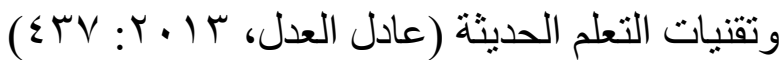

وكذلك رصد الاتجاهات الحديثة في تدريب المعلمين للإفادة منها في تحديد التدريب في مصر، ووضع تصور مقترح لتحديثه.

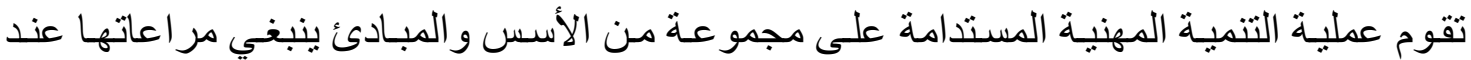

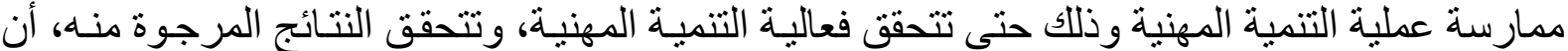

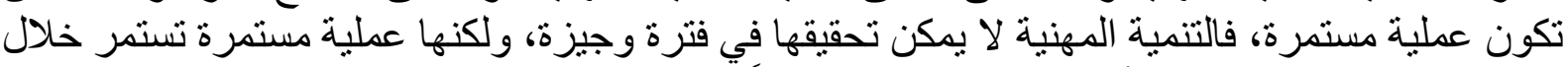

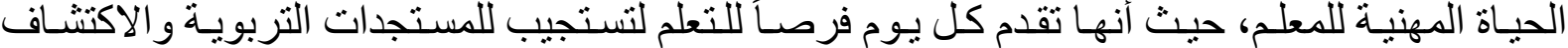

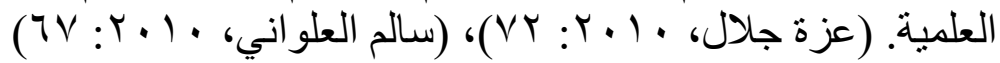

و هكذا فإن المهام الرئيسية لعملية الإشر اف التربوي (مشرفة الروضـة ) في ريـاض الأطفال هي الإني

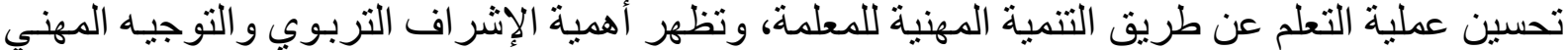

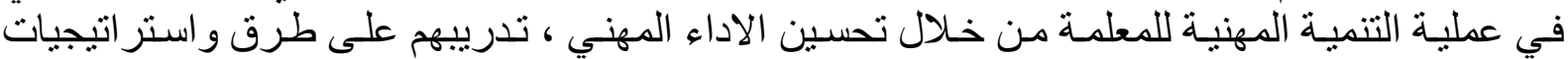
حديثة للتعلم ، تفعيل الاشر اف الإلكتروني وتدريبهم علية ،الالهتمام بـالتحول الرقمي وربط التكنولوجيـا بالنو احي التعليمية .

وبعد عرض كل التعريفات و الدر اسات سالفة الذكر نرى ان التنميـة المهنيـة تعتبر الهـدف الأسـى

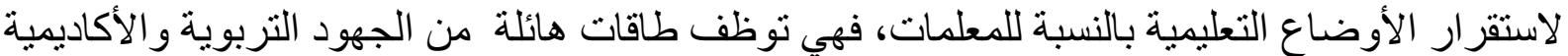
لتحسين كفاءات المعلمين و المشرفين وتستطيع المشرفات تطبيق كل الاتجاهات الحديثة في عمليتي التعليم

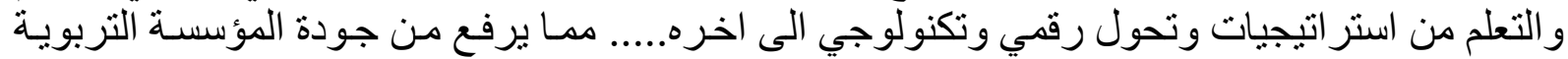
وينعكس على الاطفال 


\section{ثانياً: مشرفات رياض الأطفال}

إن الاشر اف ليس مُجرد إسداء نصح من أثخاص أكبر سنًا وخبرة إلى شخص يقل عنه في الخبرة

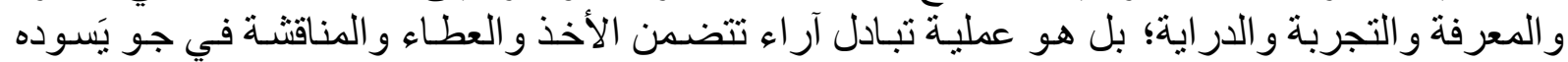

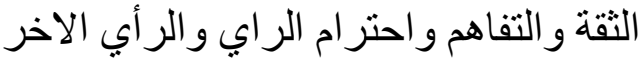

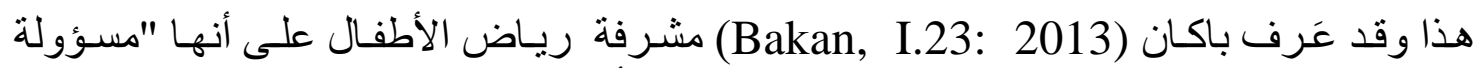

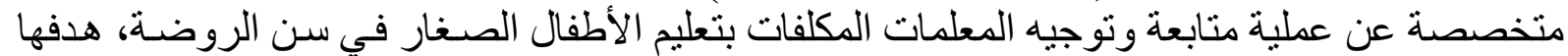
تحسين العملية التعليمية بصفة عملة منامة ونة ".

و الإشر اف عملية توجيه وتقويم للعملية التعليمية بقصد بها تزويد المتعلمين بخدمات أفضل. ،وهي وهو

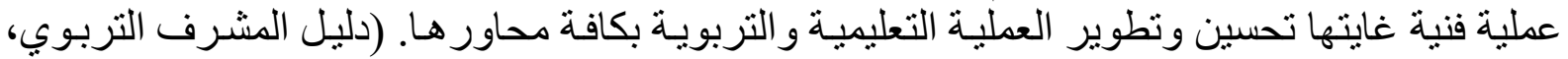

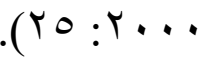

كما أن الإشر اف التربوي عملية فنية يقوم بها تربويون مختصسون بقصد النهوض بعمليتي التعليم و التعلم، وما يتصل بهما من مدخلات ومخرجات تؤدى الإنى تحقيق رؤية ورسالة المؤسسة التربوية .

و اكد كلا من بيتش ورينهارنز (Beach, D. B., \& Reinhartz, J. 2014:27) على ان

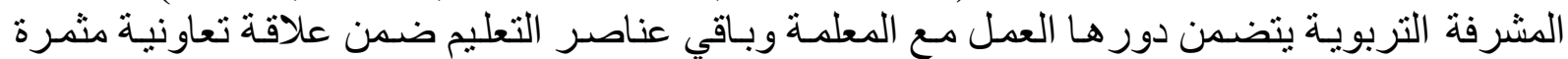

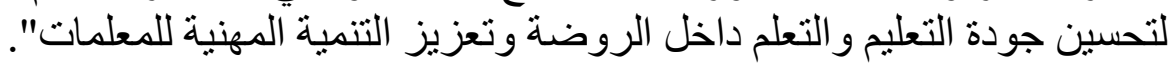

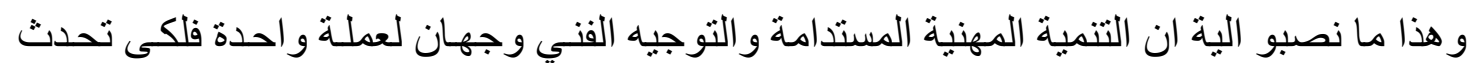

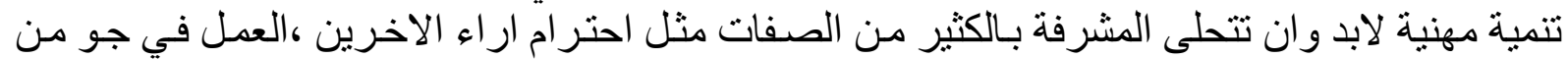

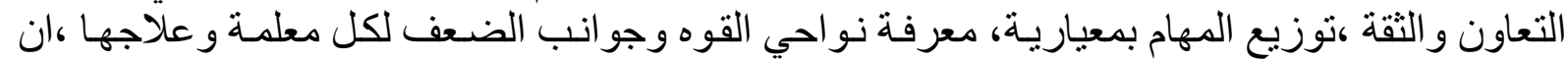
يكون هنالك وضوحا في الاهداف و هكذا

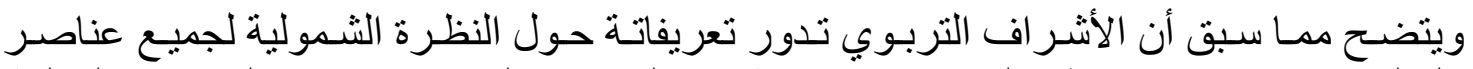

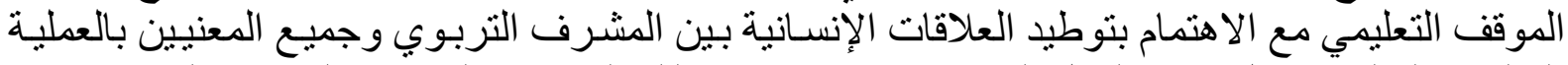

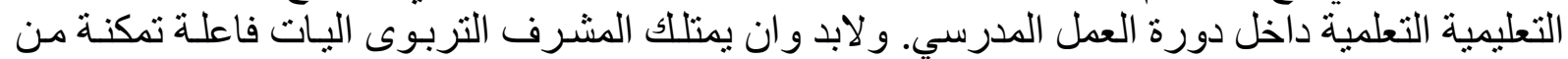

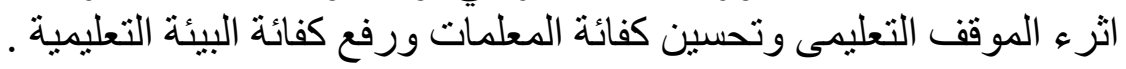

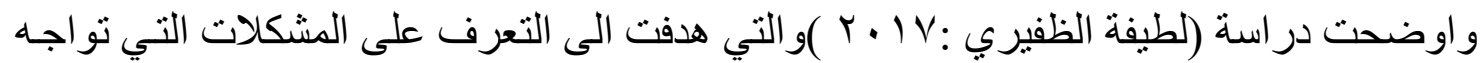
المشرفات التربويات وكان من ابرز نتائجها وجود مشكلات في البر امج التدريبية التي تقدمها التيا المشرفات

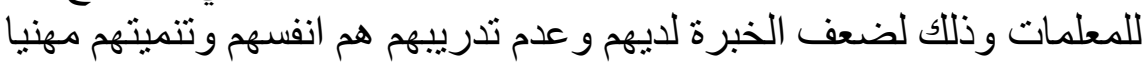

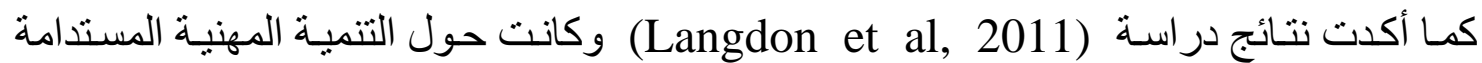

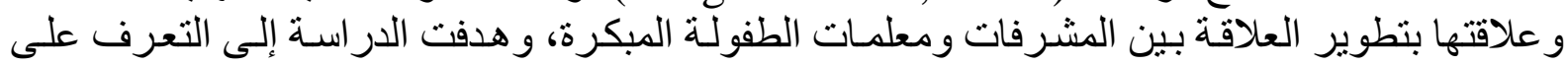

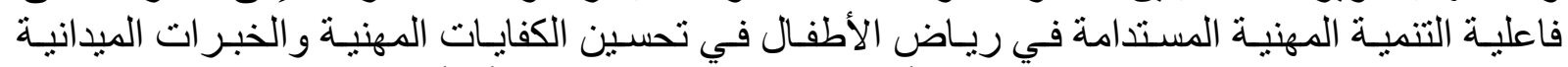

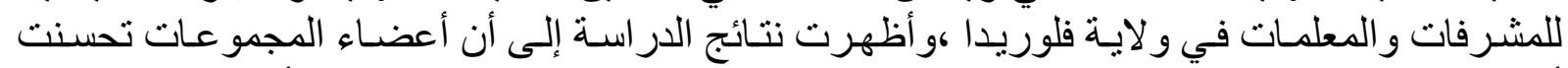

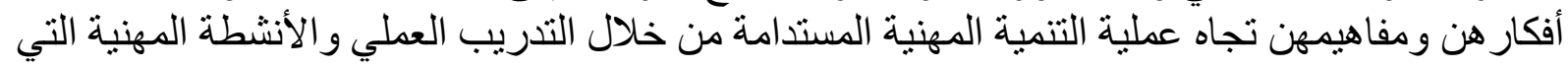

تضمنها البرنامج.

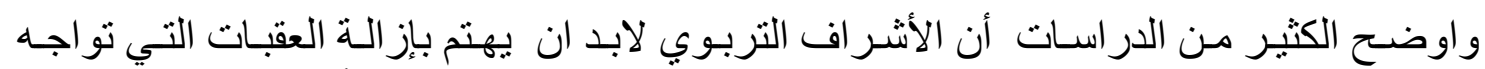

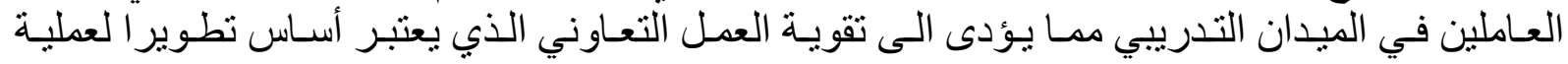
التعليمية و التّر يبية. 


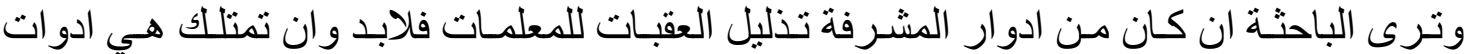

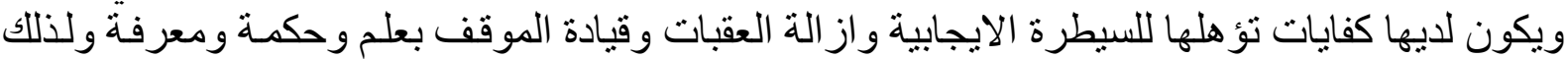
ترجع اهية البحث في وجود منطلبات تتعكس على المعلمات والاطفال والهات والمؤسسة التربوية.

$$
\text { ادوار المشرف التربوي }
$$

ويتصف دور المشرف التربوي بالثمولية في تفاعله مع عناصر المنظومة التربوية وارتباط دوره

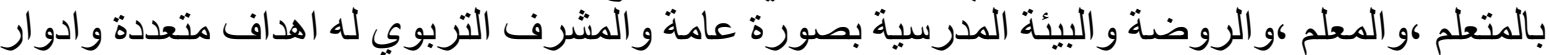

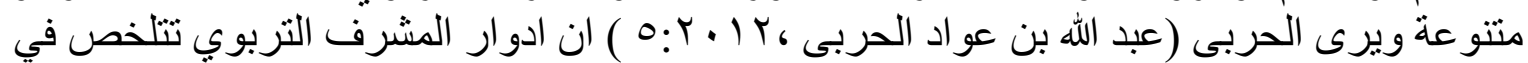

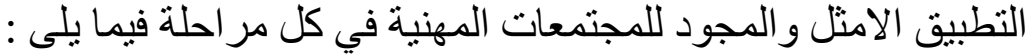

ا ـنشر ثقافة المجتمعات المهنية في البيئة التربوية وتدريب المعلمين عليها

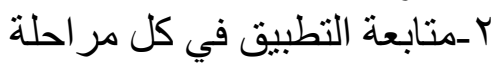

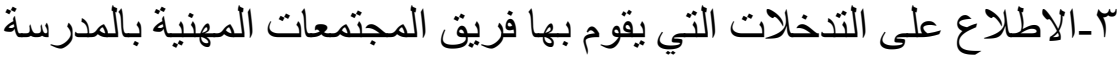

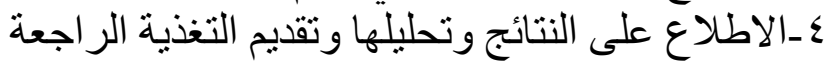
هـاعداد خطط التحسين و التطوير

7-تزويد المعلمات بالجديد في مجتمعات التعلم المهنية عن طريق التدريبات بأثكالها المختلفة

\section{أهداف الاشر اف التربوي برياض الأطفال:}

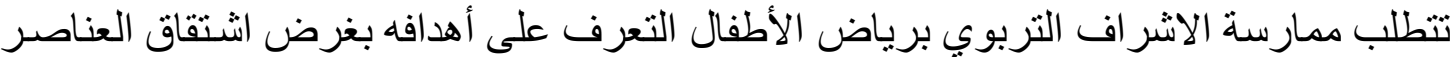

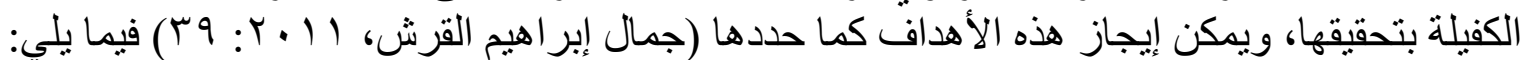

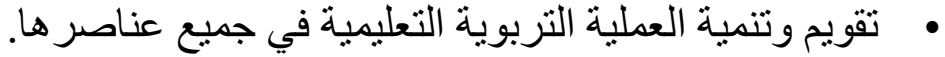

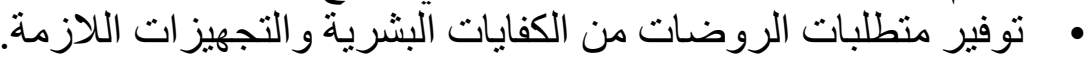

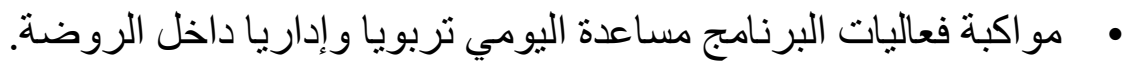

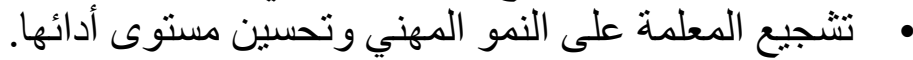

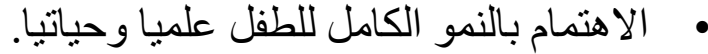
• • • • • إبيق المنهج وتطوير البر امج والأنشطة.

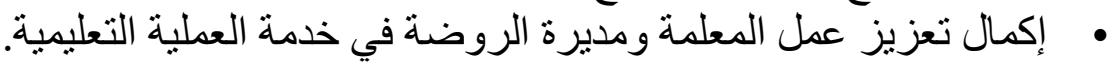

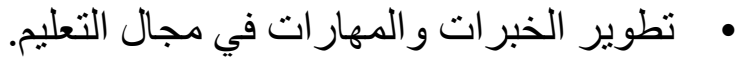

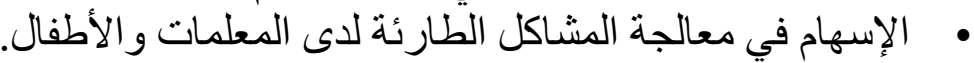

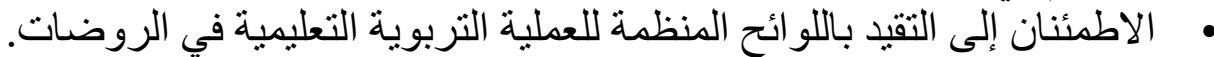

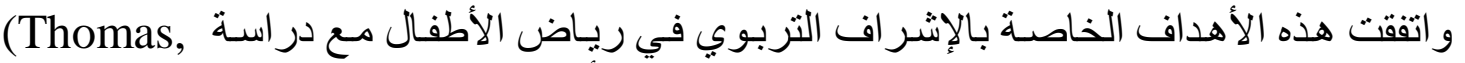

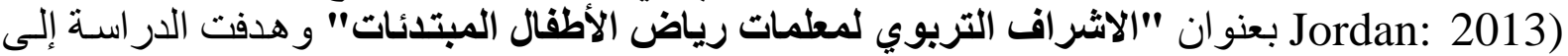

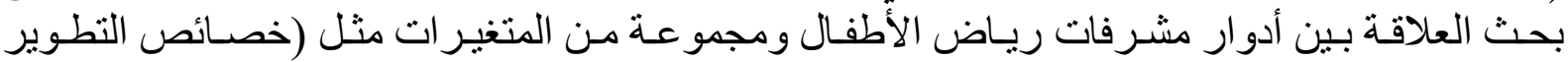

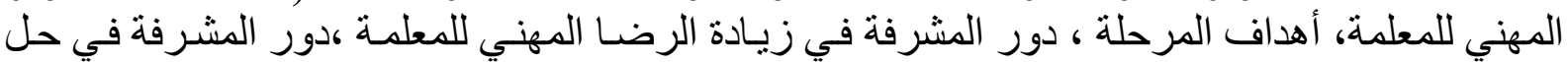

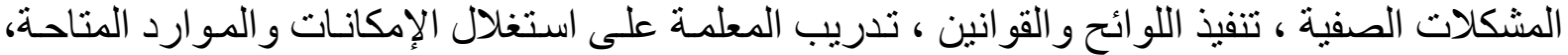

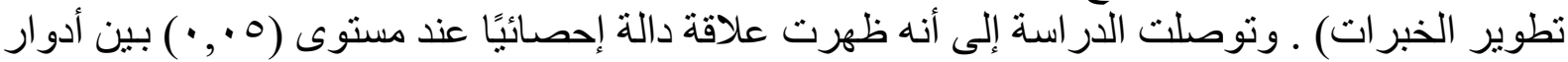
الاشر اف التربوية ودافعية المعلمات وتحسن ظروف العنه العمل بالنسبة لهم.

و ومن خـلال مـا سـبق تؤكد الباحثنة على ان الاشـر اف التربـوي هو : عمليـة إنسـانية شـاملة علميـة

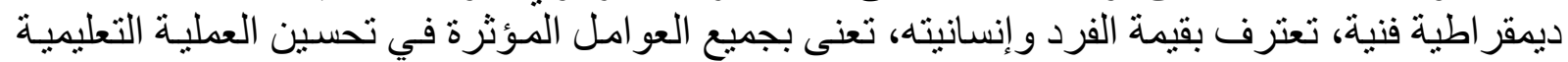

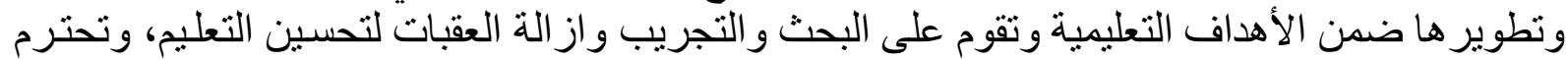

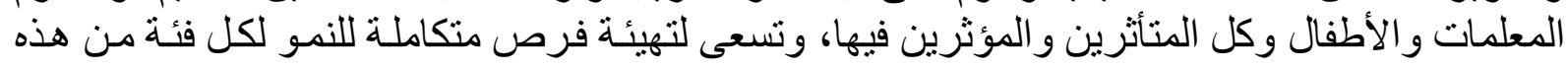


الفئات وتشجعهم على الابتكار والإبداع وذللك لاعتمادها على أسـاليب ووسـائل حديثة ومبتكرة ومتتوعة

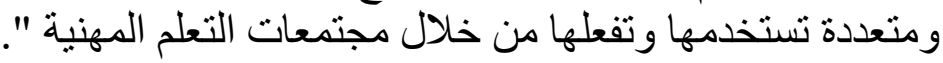

ثالثا مجتمعات التعلم المهنية

يعرف تومـاس (Thomas,2008,62) مجتمعـات التعلم المهنيـة بانـة جماعـة مـن الافر اد لـديهم

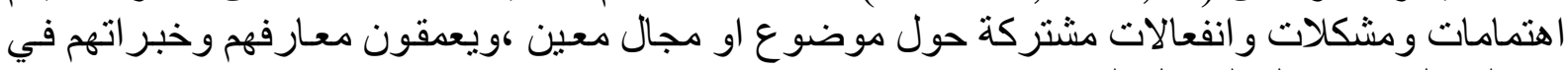
هذا المجال من خلال التفاعل المستمر .

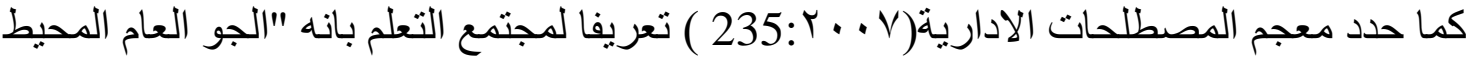
بالجماعة و الذى يشارك فيه كل العاملين في المسئولية تجاه تعليم بعضهم بشكل عملي في تحقيق ذللك "

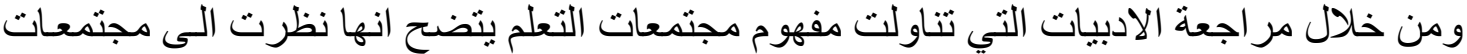

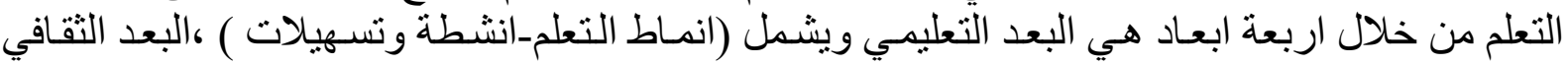

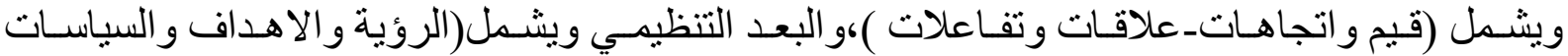

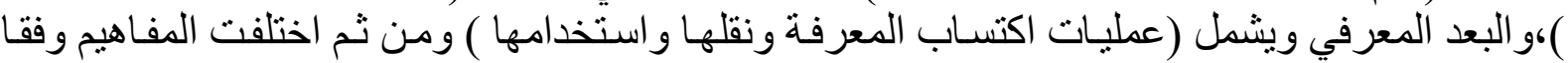

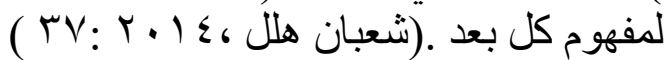

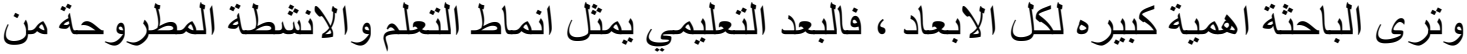

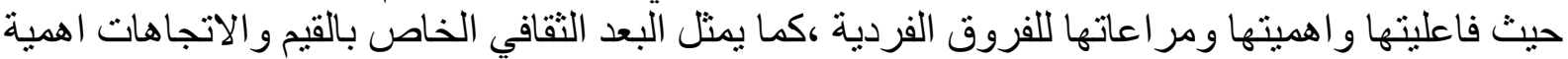
كبرى فان لم تستطيع المشرفة تغيير اتجاهات المعلمات بإيجابية الى التنمية المهنية المستدامة ومجتمعاتها

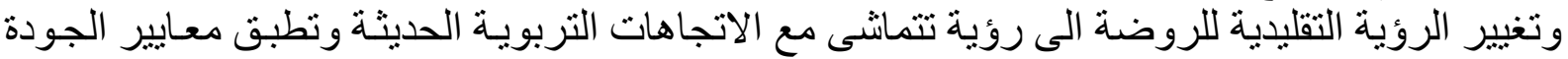

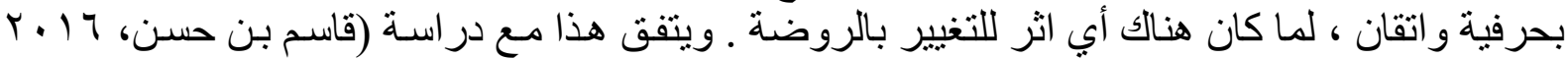

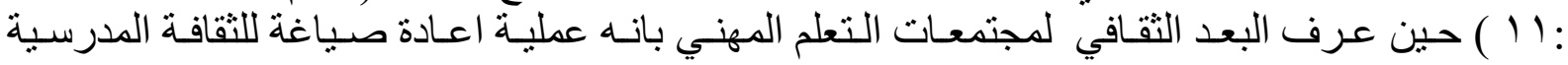

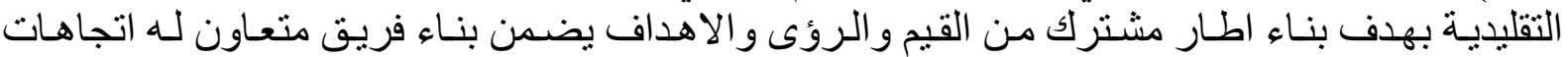
ايجابية حول التنمية المهنية و اقامة مجتمعات التعلم المهنية

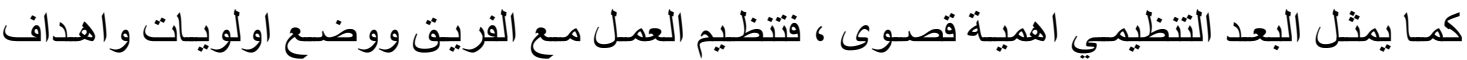

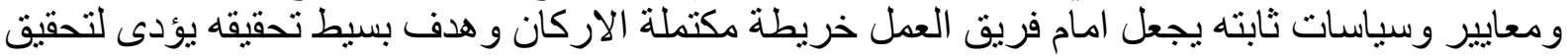

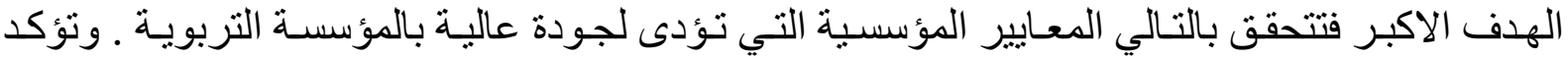

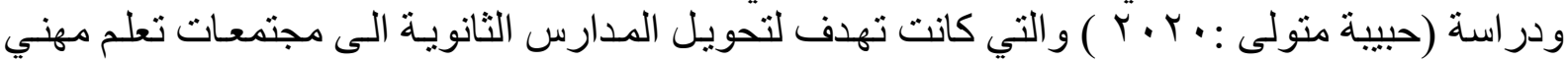

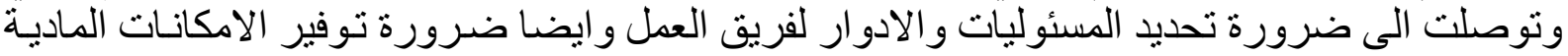

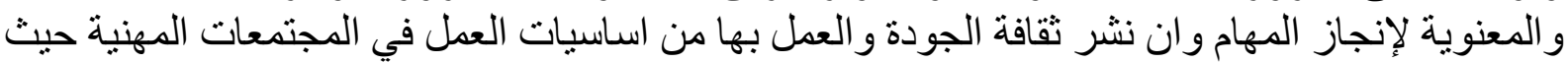
انها تهدف لبناء مؤسسات قويه تطبق الجودة كأساس في بناء المؤسسة التربوية .

\section{ا اهمية مجتمعات التعلم المهنية : -}

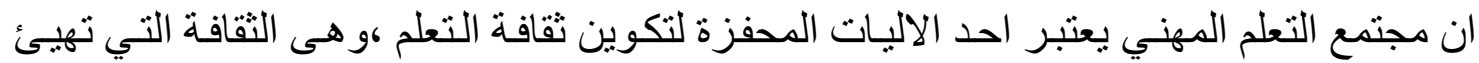
الفرص المناسبة لجميع العاملين بالمؤسسة التعليمية ليصبحو ا متعلمين مدى الحياة، ويكونو ا مشتركين في الإي تحقيق رؤية ورسالة وعمل جماعي قائم على التفكير و الابداع وتغبير الثقافة المؤسسية مدى الحئ الحياة

$$
\text { وتكمن اهمية مجتمعات التعلم المهني فيما يلى :- }
$$

ا ـ يوفر مجتمع التعلم المهني دور ا مهما في تطوير الهيئة الدر اسية شخصيا واجتماعيا ومهنيا

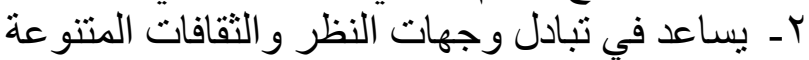
بـ تعد مجتمعات التعلم المهنية وسيلة المشرفة التربوية لنشر ثقافة التعلم و التفكير و البحث 


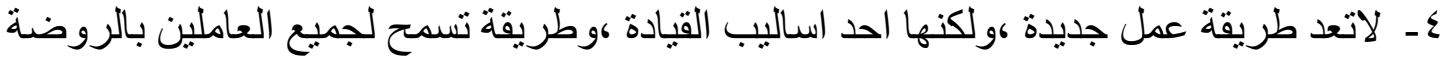

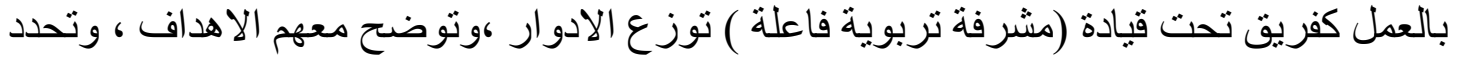

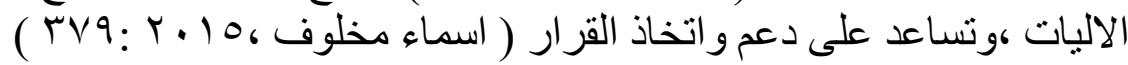

وترى الباحثة بعد العرض السبق ،ان ما يقصد بمدخل مجتمعـات التعلم المهنيـة بريـاض الاطفـال هو تحويل الروضة من النمط التقليدي المقتصر على التعليم فقط الى مؤسسـة تربويـة تعليميـة تهييـئ بيئة

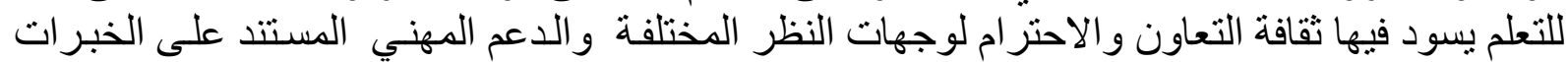

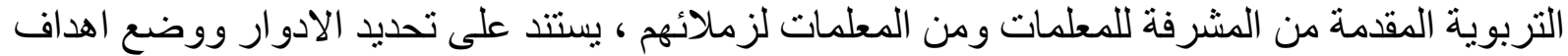

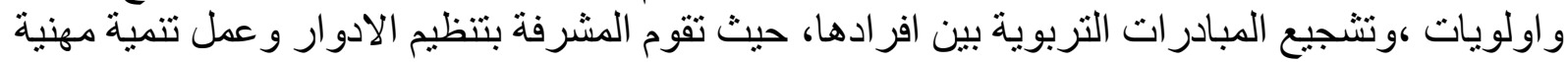

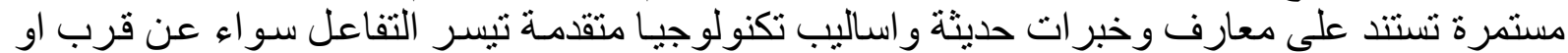

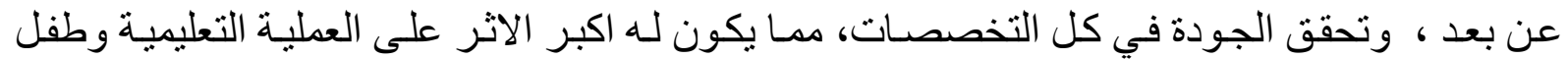

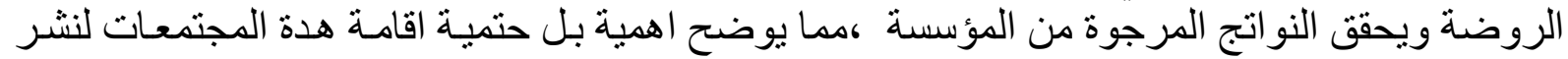

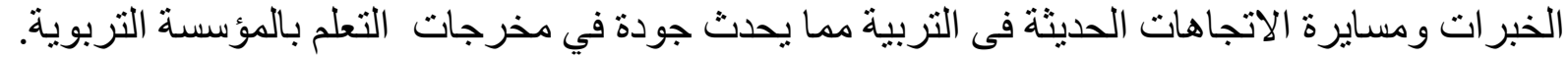

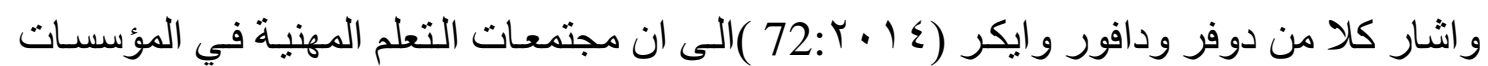

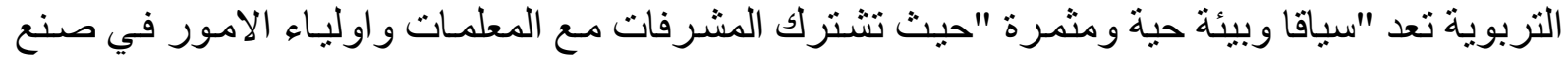

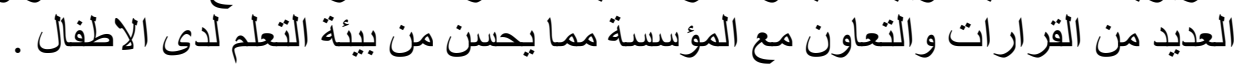

كما اثتتت الكثير من الدر اسات والبحوث ان قدرة المنظمة على التطوير ودعم عمليـة التحسين في

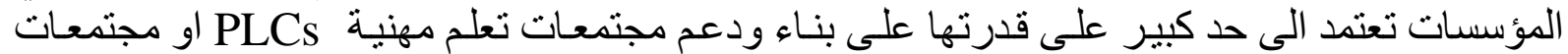

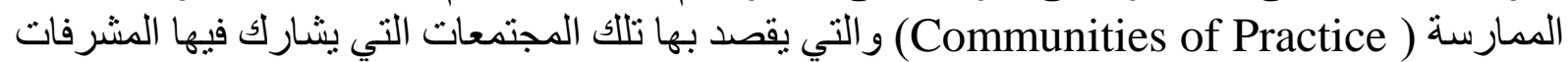
و المعلمات التربوبين جانبا الى جانب في انشطة القيادة وصنع القرار ،ويكون لديهم شعور مشترك بالتهدف

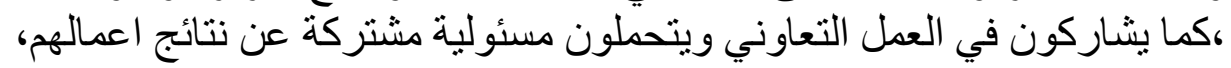

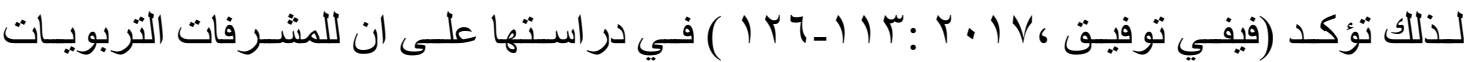

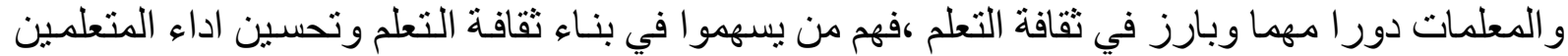

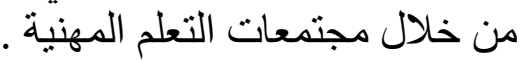

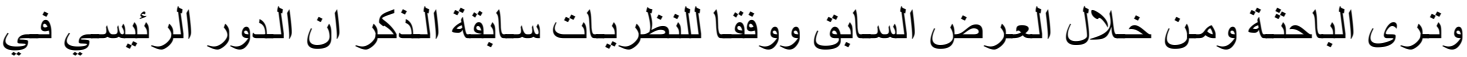

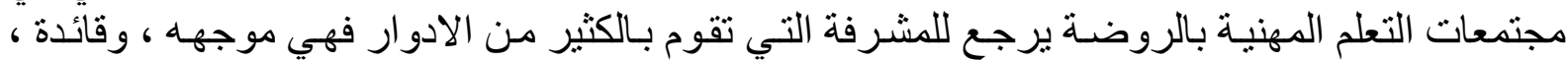

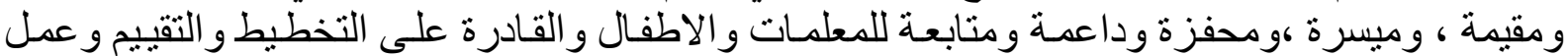

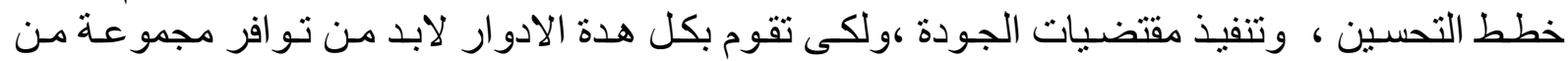

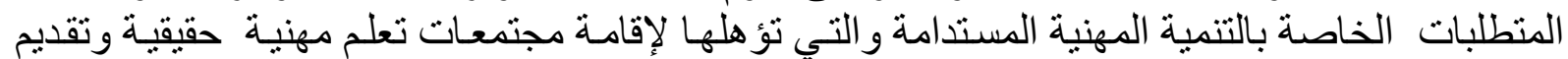

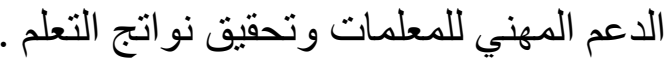

إجراعات البحث: للإجابة عن أسئلة البحث إتبعت الباحثة الإجراءات التالية: ['] [استبانة مشرفات رياض الأطفال: (ملحق رقم ا) 


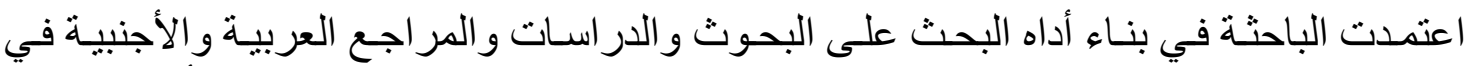

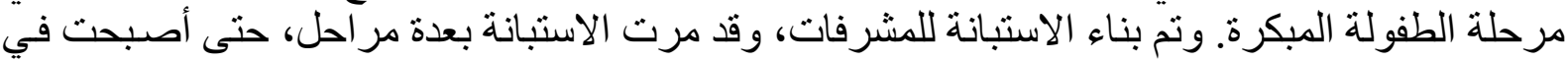
صورتها النهائية، وفيما يلي عرض وضئ للإجر اءات الخاصة بيناء الاستبانة (من إعداد الباحثة).. الههف من الاستبيان: رصد ومعرفة واقع التنمية المهنية الموجود بالفعل لدى المشرفات

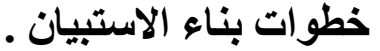

لبناء الاستبانة، قامت الباحثة بالإجر اءات التالية:

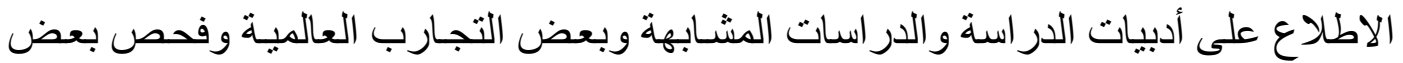
الأدو ات المشابهة وذلك بهدف تحديد المشكلة ورصد الواقع الفعلي للتنمية المهنية للمشرفات.

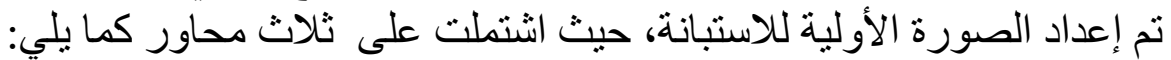
ا ـ المحور الأول: الاحتياجات المعرفية للمشرفات وتضمنت (V) عبار ات.

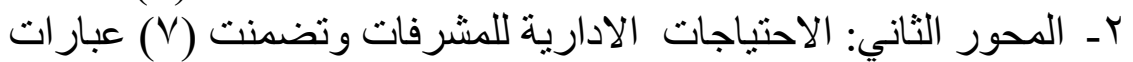

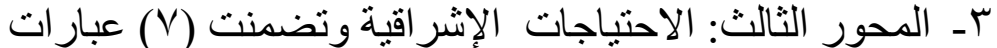

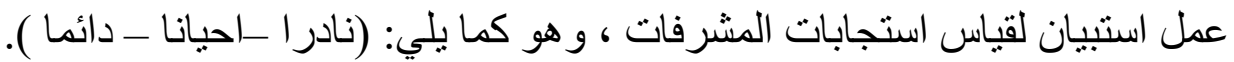
تم عمل قائمة بالإرشادات و البيانات اللازمة لاستخدام الاستبانة.

خطوات توزيعه: نظر العدم وجود تجمعات او اجتماعـات بسبب الظروف الر اهنـة قامت الباحثة

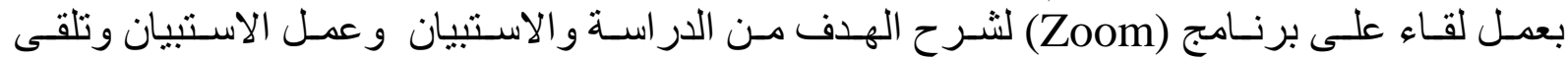

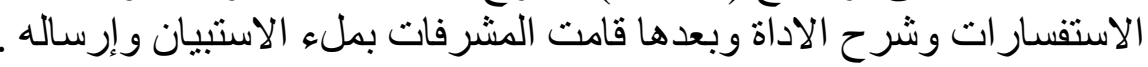

المعالجة الإحصائية للاستبانة المشرفات

أولا : صدق المحكمين

ولتحقيق هذا النوع مـن الصـدق تـم عرض المقيـاس في صـورته الأوليـة علـي عدد مـن السـادة

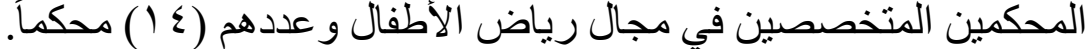
وقامت الباحثة بأجر اء التعديلات المطلوبة حيث كانت نسبة الاتفاق بينهم كبيرة و الجدول التئل التالي يوضح بعض التعديلات التي تمت على الاستبانة. ـ تعديل بعض العبارات في الصياغة اللغوية. التئ، وهي كالتالي

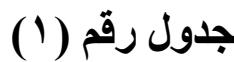

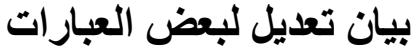

\begin{tabular}{|c|c|c|}
\hline العبارة بعد التعديل & العبارة قبل التعديل & 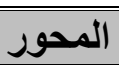 \\
\hline تعرف الجديد في مجال تقييم الاداء للمعلمة & 0-تستطيع ان تقييم المعلمة & \multirow[b]{2}{*}{ 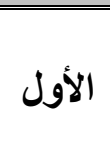 } \\
\hline تتندرب على استراتيجيات حل المشكلات & لوشككلات طـرق متتوعـة تسـاعدها في حلل & \\
\hline 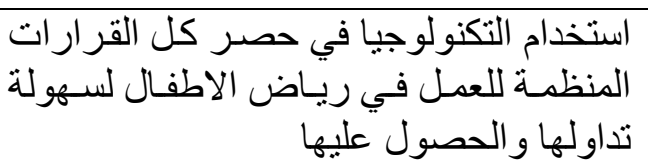 & علمها_تستطيع استخدام التكنولوجيا في توظيف & الثاني \\
\hline تبالبيئة & 1-تنساعد المعلمات في توظيف المنهج & \multirow[t]{2}{*}{ الثالث } \\
\hline التخطيط الفعال لأشر اف التربوي & آ-تخطط وفقا للمعطيات & \\
\hline
\end{tabular}


الاساليب الاحصائية المستخدمة

\section{Reliability: معامل ثبات ألفا كرونباخ}

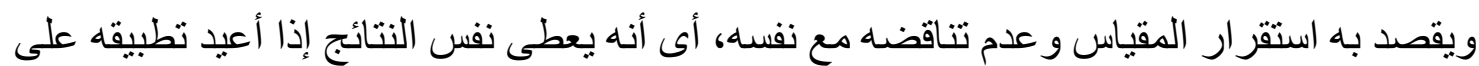

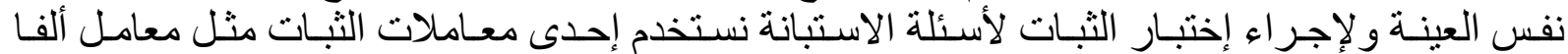

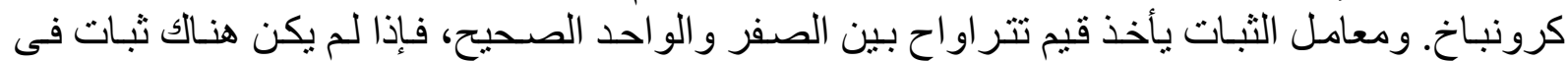

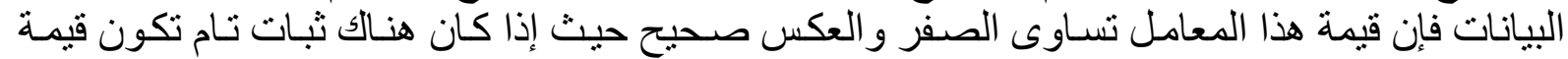

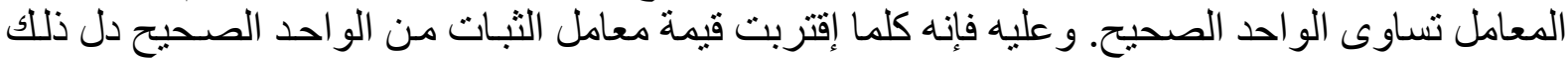
على وجود ثبات فى البيانات (استجابات أفر اد العينة).

Validity: صدق الاتساق الداخلي

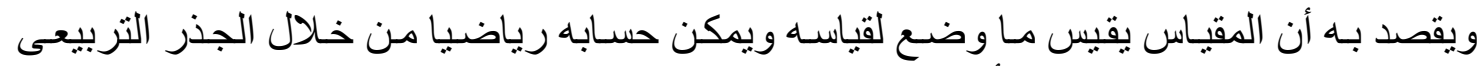

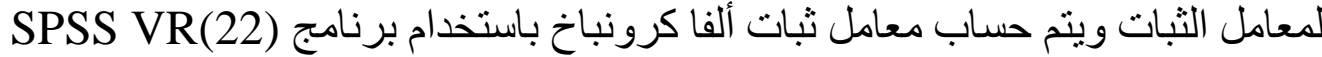

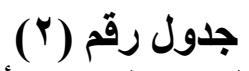

معاملات الثبات و الصدق لمحاور أستبيان المشرفات

\begin{tabular}{|c|c|c|c|}
\hline معامل الصدق & معامل الثبات & عدد الفقرات & الأحتياجات \\
\hline$\cdot, 9$ & $\cdot, \wedge 1$ & $\mathrm{v}$ & الاحتباجات المعرفية للمشرفات \\
\hline$\cdot, 9$. & $\cdot, \wedge 1$ & $\mathrm{v}$ & الاحتياجات الادارية للمشرفات \\
\hline$\cdot, 91$ & $\cdot, \wedge 1$ & $\bar{v}$ & الاحتياجات الأثر افية \\
\hline$\cdot 9 \mathrm{~V}$ & $\cdot, 9 \xi$ & YI & الاجمالى \\
\hline
\end{tabular}

ويتضح من الجدول السابق قيم معاملات الثبات ألفا كرونباخ لأبعاد الاستبانة وكانت جميعها أكبر

$$
\text { من (·A, · ) وهى نسب مرنفعة جدا. }
$$

ويمكن حساب الاتساق الداخلي للإستبانة وذللك من خلال حساب معاملات الارتباط بين كل فقرة من فقر ات مجالات الإستبانة و الدرجة الكلية للمجال نفسة.

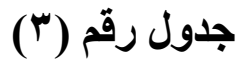

الاتساق الداخلى لفقرات محور الاحتياجات المعرفية للمشرقات

\begin{tabular}{|c|c|c|}
\hline معامل الارتباط & الاحتياجات المعرفية للمشرفات & \\
\hline$* *,, \leqslant 0$ & توجد تدريبات مهنية للمشرفات توفر المعلومات الضرورية لأداء عملها & - \\
\hline$* *$, oV & تنمى لديها المفاهيم الخاصة بمجال رياض الأطفال & - \\
\hline$* * \cdot, 71$ & تعرف استر اتيجيات التعليم الحديثة برياض الأطفال & - \\
\hline$* * ., 0 Y$ & تخطط لتفعيل مشـاركات مؤسسات المجتمع المحلى مع الروضة. & - \\
\hline$* *, 09$ & تعرف الجديد فى مجال تقييم الأداء للمعلمة & - \\
\hline$* *, 0 \wedge$ & تتعرف على آخر المستحدثات في مناهج رياض الأطفال & - \\
\hline$* *, \Gamma V$ & تتدرب على استر اتيجيات حل المشكلات. & - \\
\hline
\end{tabular}

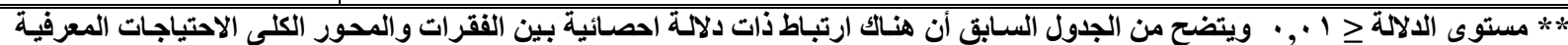

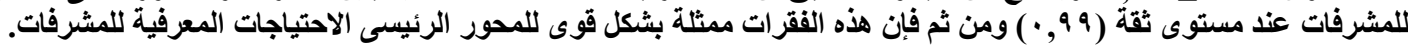


المحور الثانى: الاحتياجات الادارية للمشرفات

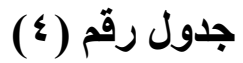

الاتساق الاخلى لفقرات محور الاحتياجات الادارية للمشرفات

\begin{tabular}{|c|c|c|}
\hline معامل الارتباط & الاحتياجات الادارية للمشرفات & \\
\hline$* *, 07$ & إتباع الأسلوب العلمي في عقد الاجتماعات مع المعلمات & - \\
\hline$* *, \leqslant$ & التخطيط للزيار ات الميدانية للروضات & - \\
\hline$* *, \mu q$ & التخطيط للتنمية المهنية الذاتية & - \\
\hline$* * \cdot, r \leqslant$ & التخطيط للتنمية المهنية لمعلمة الروضة & - \\
\hline$* *, r r$ & الإشر اف على الدورات التدريبية القصيرة (فنياً و إدارياً) & - \\
\hline$* *, \mu$ & الإشر اف على تنفيذ الخطط التعليمية للوزارة & - \\
\hline$* *, \Sigma$ & لسهولة داولها التكنولو الحصول في حصر كل القرارات المنظمة للعمل في رياض الأطفال & - \\
\hline
\end{tabular}

•, + مستوى الدلالة

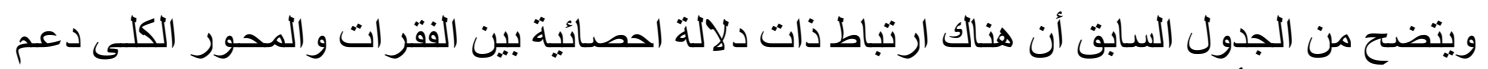

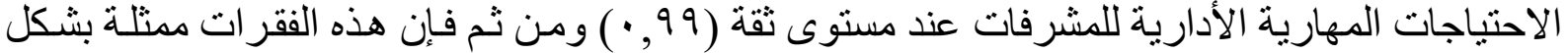
قوى للمحور الرئيسى الاحتياجات المهارية الأدائية للموجهات

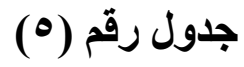

الاتساق الداخلى لفقرات محور الاحتياجات الاشرافية للمشرفات

\begin{tabular}{|c|c|c|}
\hline معامل الارتباط & الاحتياجات الاشر افية للمشرفات & \\
\hline$* *, \wedge \varepsilon$ & تساعد في توجيه المعلمات لربط المنهج الجديد بالبيئة. & - \\
\hline$* *,, V V$ & مشاركة المعلمات في إعداد وتطوير رسالة الروضة & - \\
\hline$* * \cdot, \wedge$ & مشاركة المعلمات في تخطيط البر امج الأسبو عية والثهرية و السنوية . & - \\
\hline$* *, \mathrm{VV}$ & إتباع الأسلوب العلمي في عقد الاجتماعات مع المعلمات. & - \\
\hline$* * \cdot, \wedge$ & استخدام أساليب وطرق تناسب الأهداف الموضو عية للبر امج اليومية. & - \\
\hline$* * \cdot, \wedge \wedge$ & التخطيط الفعال للإشر اف التربوي. الت & - \\
\hline$* * \cdot, \mu_{0}$ & استخدام الأساليب المناسبة للإشر اف التربوي. & - \\
\hline
\end{tabular}

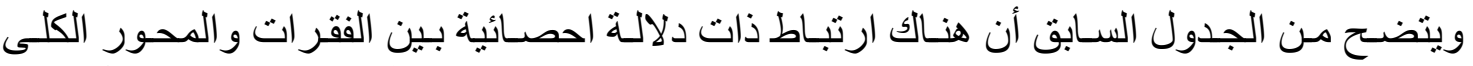

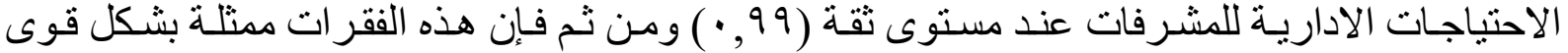
للمحور الرئيسى الاحتياجات الادارية للمشرفات

نتائج البحث و تقسير ها للإجابة عن السؤال الأول للبحث و الذي ينص على:

ما واقع التنمية المهنية المستدامة لمشرفات رياض الأطفال ؟

وفيما يلى عرض نتائج تطبيق أستبيان مشرفات رياض الأطفال عن و اقع التنمية المهنية المستدامة ل لمشرفات رياض الأطفال (ملحق رقم ؟). 
المحور الأول:- الاحتياجات المعرفية للمشرفات

جدول رقم (7) جلات

التوزيع التكرارى والنسبى ـ معامل اختلاف ـ الأهمية النسبية

لمحور الاحتياجات المعرفية للمشرفات النيات

\begin{tabular}{|c|c|c|c|c|c|c|c|c|}
\hline \multirow{2}{*}{ مربع كاى } & \multirow{2}{*}{ معامل الاختلاف } & \multicolumn{2}{|c|}{ دائما } & \multicolumn{2}{|c|}{ أحيانـا } & \multicolumn{2}{|c|}{ نادرا } & \multirow{2}{*}{ العبارة } \\
\hline & & نسبة & عدد & نسبةة & عدد & نسبة & عدد & \\
\hline 7. rᄉ. & $\%$ \%r. 1. & $\%$ \%q.. & rq & $\%$ \%^. & rA & $\%{ }^{\mu}{ }^{\mu}$. & $\mu$ & 1 \\
\hline VI.VA. & $\%$ YI.9 & $\%$ \% . & r7 & $\%$ YV. & TV & $\%$ Y. & $r$ & $r$ \\
\hline 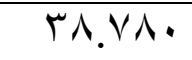 & \% & $\% 11$. & 11 & $\% \Gamma \cdot . \cdot$ & r. & $\%$ \%^. & rA & $r$ \\
\hline$\leqslant 0.0 \ldots$ & $\% \Gamma \cdot . \wedge$ & $\% 10$. & 10 & $\% 19$. & 19 & $\% 10$. & 10 & $\varepsilon$ \\
\hline$\leqslant 0 . Y 7$. & $\%$ Yq.Yo & $\% 19$. & 19 & $\%$ \%r. & r & $\% 10$. & 10 & 0 \\
\hline r.. 7. & $\% \sqcap q . \leqslant 0$ & $\%$ \%q. & rq & $\%$ ro. & ro & $\% 1 \cdot$. & 1. & 7 \\
\hline$\leqslant 0.7 Y$. & $\% \mu^{\prime \prime} . \leqslant Y$ & $\% \vee$. & V & $\% \Gamma \cdot$. & $r \varepsilon$ & $\% \Gamma \cdot$. & r. & V \\
\hline
\end{tabular}

مناقثة وتفسير نتائج المحور الاول (الاحتياجات المعرفية للمشرفات )

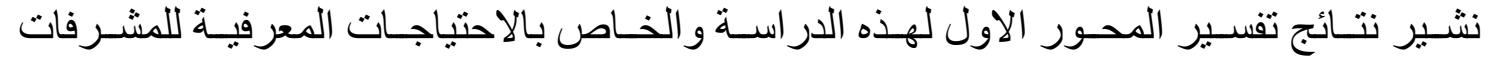

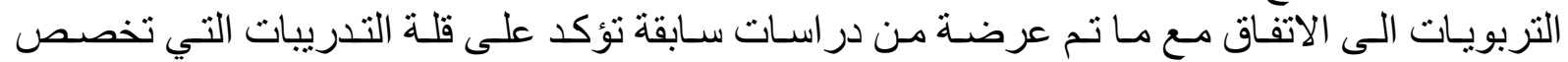

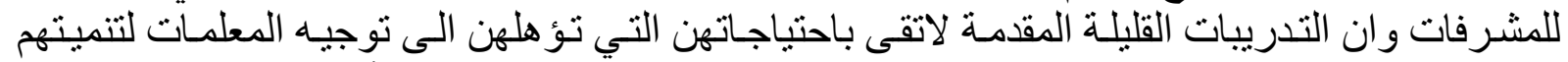

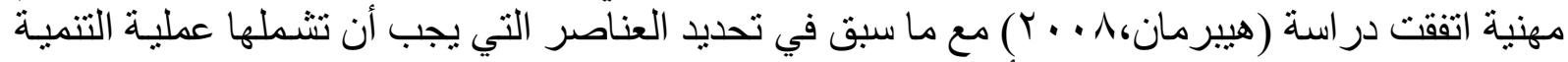

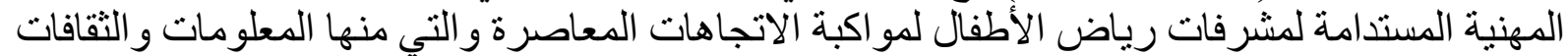

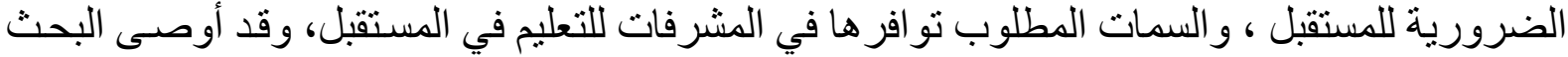

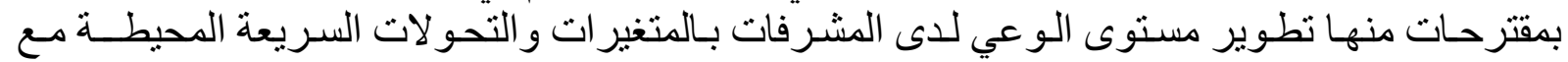

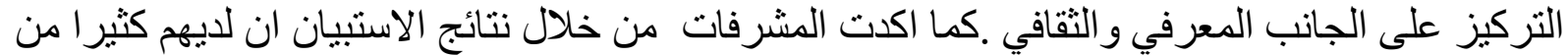

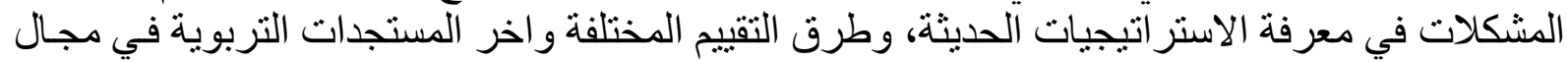

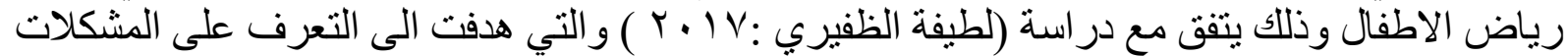

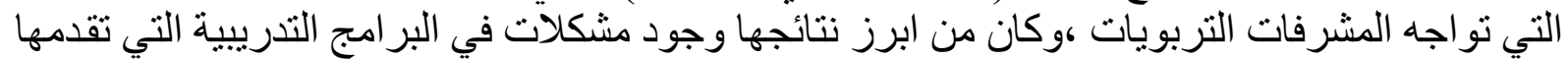

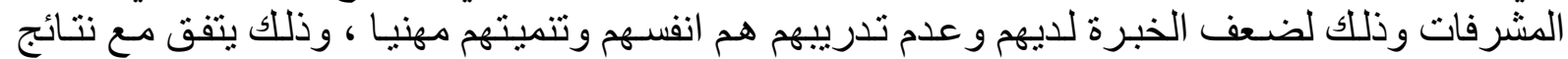
الدر اسة في افتقار المشرفات الى كثير من النواحي المعرفية والتدريبية والتي تجعلهم لا يستطيعون تقديم

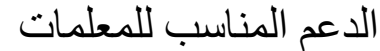

المحور الثانى :- الاحتياجات المهارية الأدرية للمشرفات

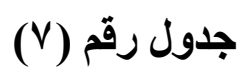

التوزيع التكرارى والنسبى - معامل اختلاف ـ الأهمية النسبية

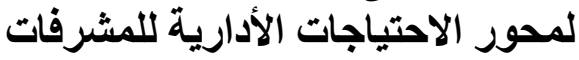

\begin{tabular}{|c|c|c|c|c|c|c|c|c|c|}
\hline \multirow{2}{*}{ كاى مربع } & \multirow{2}{*}{ الأهمبة النسبية } & \multirow{2}{*}{ معامل الاختلاف } & \multicolumn{2}{|c|}{ دائما } & \multicolumn{2}{|c|}{ أحيانا } & \multicolumn{2}{|c|}{ نـادرا } & \multirow{2}{*}{ العبارة } \\
\hline & & & نسبةة & عدد & نسبةة & عدد & نسبةة & عدد & \\
\hline $17.0 \leqslant$. & $\% 79 .$. & $\%$ \%r. & $\% 10$. & 10 & $\% \vee \vee$. & TV & $\%$ \%.. & $\Lambda$ & 1 \\
\hline$r \leqslant .0 \wedge$. & $\% 7 V .7 V$ & $\% \Gamma \cdot . \wedge \wedge$ & $\%$ \%l. & YI & $\% 71$. & rT & $\% \backslash \wedge$. & 11 & r \\
\hline OV.TY. & \% & $\%$ YV.19 & $\% \backslash \wedge$. & 11 & $\% 79$. & 19 & $\%$ & $\pi$ & $r$ \\
\hline Tะ.17. & $\% V \cdot .7 V$ & $0 / 4 q . \leqslant \varepsilon$ & $\%$ \%ч. & rT & $\% 7 \cdot . \cdot$ & r. & $\%) \leqslant$. & $1 \varepsilon$ & $\varepsilon$ \\
\hline$\Sigma \Gamma . \wedge Y$. & $\% \vee \cdot \ldots$ & $\%$ \%^.ル & $\%$ \%r. & rT & $\% \curlyvee$ \%. & T乏 & $\%$ & $1 \pi$ & 0 \\
\hline rq.11. & $\% \wedge \wedge$ & $\%$ \%7.9V & $\%$ YV. & TV & $\%$ \%q. & rq & $\% 9$. & 9 & 7 \\
\hline$\varepsilon 0.1 \leqslant$. & $\% 7 V .$. & $\%$ \% .०人 & $\% \backslash \wedge$. & 11 & $\% 70$. & TO & $\%) \vee$. & IV & $\mathrm{V}$ \\
\hline
\end{tabular}




\section{مناقشة وتفسير نتائج المحور الثاني (الاحتياجات الادارية للمشرفات )}

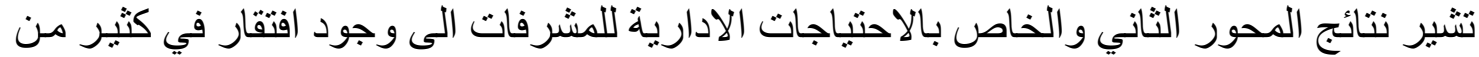

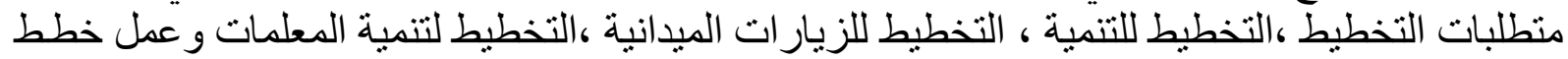
تحسين لهم و هذا لندرة الدور ات التدريبية للمشرفات في هذا المجال الخاص بالتخطيط و المهار ات التادية التائية

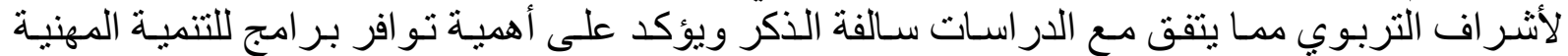

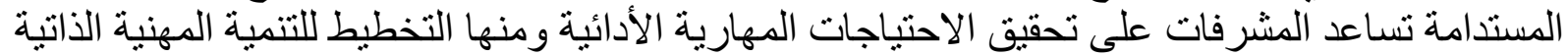

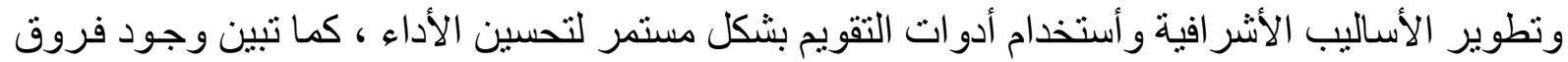

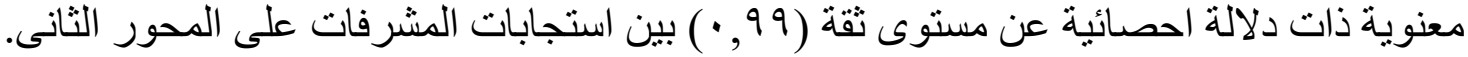

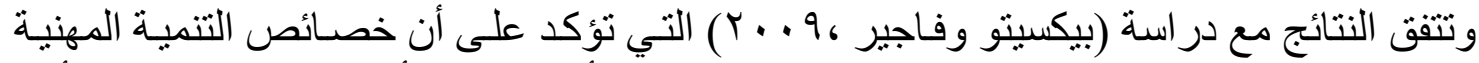

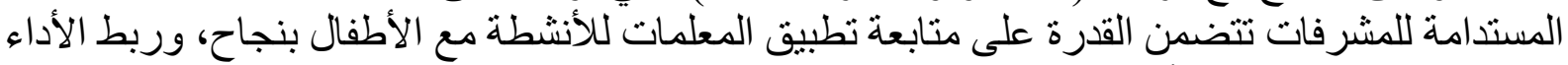

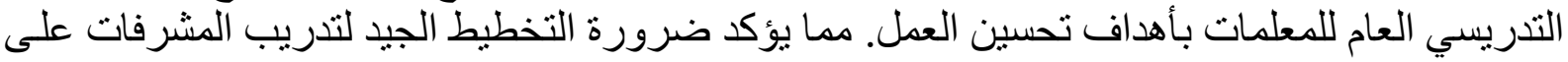

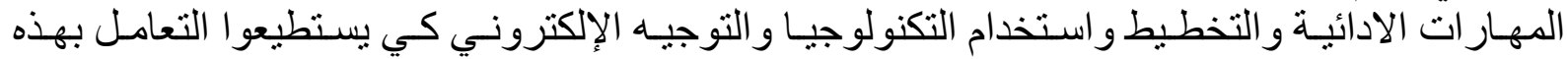

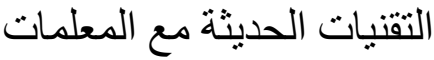
المحور الثالث :- الاحتياجات الأشرفية للمشرفات

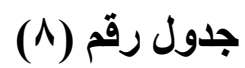
التوزيع التكرارى والنسبى - معامل اختلاف ـ الأهمية النسبية لمحور الاحتياجات الاشر افيه للمشرفات الأنيات

\begin{tabular}{|c|c|c|c|c|c|c|c|c|c|}
\hline \multirow{2}{*}{ مربع كاى } & \multirow{2}{*}{ الأهمية النسبية } & \multirow{2}{*}{ معامل الاختلافت } & \multicolumn{2}{|c|}{ دائما } & \multicolumn{2}{|c|}{ أحيانا } & \multicolumn{2}{|c|}{ نادرا } & \multirow{2}{*}{ العبارة } \\
\hline & & & نسبةة & عدد & نسبةة & عدد & نسبةة & عدد & \\
\hline rq. r. & \%०9.r & $\%$ & $\% 9$. & 9 & $\% Y \varepsilon$. & $Y \varepsilon$ & $\%$ r.. & r. & 1 \\
\hline$\Gamma \leqslant \leqslant 7$. & \% & \% & $\% 19$. & 19 & $\%$ \% . & rq & $\% r \cdot . \cdot$ & $r \cdot$ & $r$ \\
\hline$r . . T$. & \% & $\%$ \% .^० & $\%$ \%. & IT & $\%$ \% . & $r \varepsilon$ & $\%$ r. & $r$. & $r$ \\
\hline $9 . Y 7$. & $\% 09.7 \mathrm{~V}$ & $\% \leqslant 1 . \leqslant \wedge$ & $\% 19$. & 19 & $\%$ \%q. & rq & $\%$ Y... & $r \cdot$ & $\varepsilon$ \\
\hline$\varepsilon . \wedge \wedge$. & $\% 7 \cdot .7 V$ & $\% \leqslant r . \vee 0$ & $\%$ \% . & $r \varepsilon$ & $\%$ \% . & $r \wedge$ & $\%$ \% .. & ry & 0 \\
\hline 17.77. & \%०ะ.r & $\%$ & $\% 9$. & 9 & $\%$ Yo.. & rY & $\%$ ro. & ro & 7 \\
\hline $1.7 \leq$. & \%09.T & $\% \leqslant 1.1 \mathrm{~V}$ & $\% \backslash \wedge$. & 11 & $\%$ rq. & r & $\%$ Y 9. & rq & V \\
\hline
\end{tabular}

مناقثة وتفسير نتائج المحور الثالث(الاحتياجات الإثرافي للمشرفات التربويات )

وقد تبـين وجـود فروق معنويـة ذات دلالـة احصـائية عـن مسـتوى ثقـة (9 9, • ) بـين اسـتجابات

المشرفات على المحور الثالث. وتوكد النتائج حاجة المشرفات الى التدريب على عمل الخطط التعليمية مع المعلمـات ،و انهم في حاجـة الى التدريب على اسـاليب تكنولوجيـة متقدمـة في ادارة الاجتماعـات ،و انهم يفتقدو كثير ا من اساليب الاشر اف التربوي وفقا لاتجاهـات الحديثة في التربيـة ممـا يجعلهم غير قادرين على نقلها للمعلمات و ويجعل العلاقة بينهم ليست بها القدر المناسب من المرونـه ويتفق ذلك مـع مـا أكدة (فليمينج و لاف ، 1 ( • Y) أن مشرفات رياض الأطفال في حاجة التدريب على فنون القيادة، و التفرقة بين القيادة و الإتباع، فهي علاقة لا يمكن أن تكون خطية ابداً. يشجع هذا الدور معلمات رياض الأطفـال على 
السعي لاستقبال المعـارف الجديدة، وتطوير اسـالييهن في العمل في ظلل الإطـار التعاوني للعلاقـة هـع

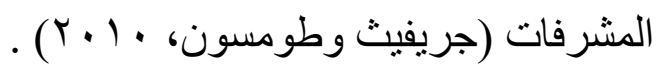

وقد كان تحديد الاحتياجات التدريبية والإشر اقية محل اهتمـام كما اوضحت دراسـة ( عبدالكريم : • • ب )للمهارات الإشر افية التي يحتاجها المشرفون التربويون في مديريات التربية والتعليم

ومن العرض السابق لنتائج المحاور الثثلاثة تؤكد نتائج الدراسـة افتقار المشرفات الى كثير ا من منطلبـات التنميـة المهنية و التـي تجعلهم غير قادرين على اقامـة مجتمعات للتعلم المهني للمعلمـات ففاقد

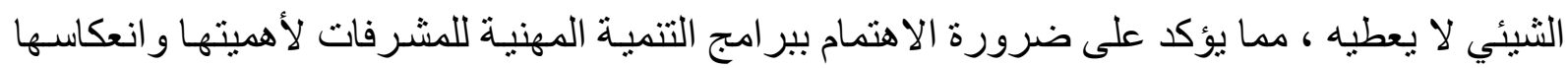
على كل اطر اف العملية التعليمية

\section{وللإجابة على السؤال الثاني والذي ينص على :} ـ ما متطلبات مجتمعات التعلم المهنية للمشرفات التربويات برياض التهي الأطفال؟

إذا كان التعلم الذاتي قائم على تعلم الفرد بذاته، فمجتمعات التعلم المهني تجمع كل القائمين على العمل وفقاً لتخصصهم ويقوموا بدراسة كل المستجدات و عرض أهم الخبرات و الأفكار الجديدة و الخبرات الذاتية على بعضهم البعض في جو من التعاون و المشاركة وتبادل المعارف و الخبرات

وتتميز مجتمعات التعلم المهنية بالبحث المستمر عن التحسين والتطوير من خـلال تعزيز النمو

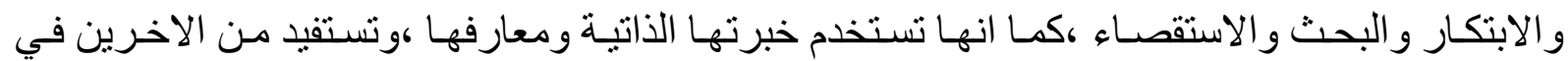

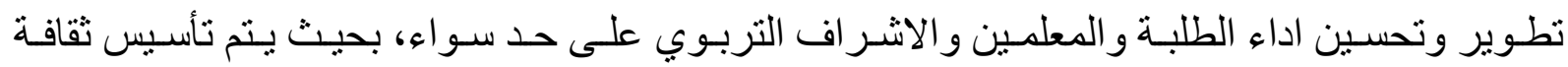
المسؤولية المشتركة للجميع ،بالإضـافة الى اتاحة فرص التعلم امـام جميع الاعضـاء و الاطر اف المعنية

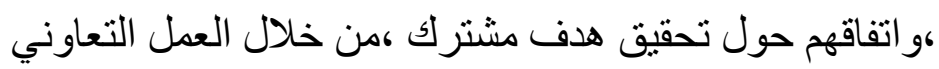
مبررات الحاجة لتفعيل مجتمعات التعلم المهني برياض الاطفال .

أن مجتمعات التعلم المهنية برياض الاطفال التي تقوم عليها المشرفات التربويات تمثل ضرورة

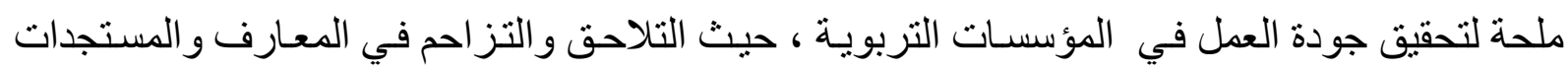
التربوية ،ووجود خريجات جدد يحتاجون الى دعم فنى وايضـا الخريجات القدامى والذين يحتاجون الى الى

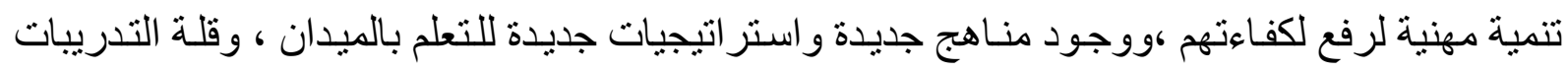

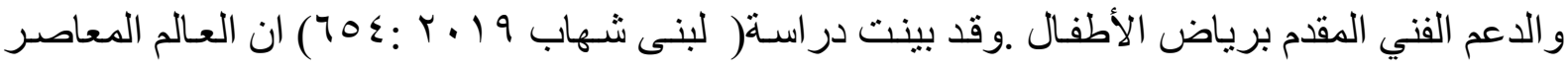

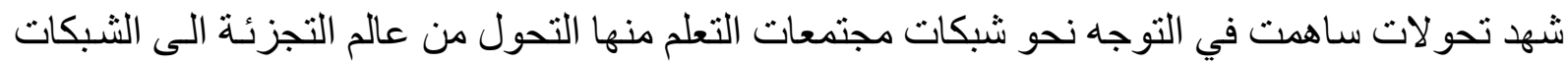


المتصلة و المندمجة والتحول من عالم الصناعة الى عـالم المعرفة هذا بالإضـافة الى الثورة الرقيـة ،كل ذللك لابد ان يجعل المعلمين يشعروا وبقوه الى الحاجـة الماسـة الى التنميـة المهنيـة ومجتمعـات التعلم حتى يستطيعو ا الحاق بركب التطور و التغير في ظل الثورة المعرفية التكنولوجيا الموجودة .

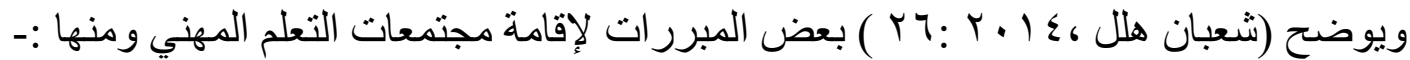

قلة تشجيع التعلم الذاتي وسيادة الروح الفردية وقلة الايمان روح الفريق قلة مصادر المعرفة المتاحة بالمؤسسات التعليمبة هيمنة المركزية بشكل يعرقل الابداع الفردي و الجماعي ضعف استخدام المعرفة و التكنولوجيا من قبل العاملين بالمؤسسة التعليمية بكفاءة ضــف ثقافـة الـتعلم داخـل المؤسسـة ،وتحويـلـ المتعلمـين الـى بـاحثين قـادرين على التوصـل للمعلومات

و من خلال ما توصلت الية الدر اسة الحالية في الإطار النظري و الدر اسة المبدانية تبين مدى وجود قصور في ، الاحتياجات المعرفية والمهارة و التدريبيـة و الإداريـة والإشـر اقية لمشرفات بريـاض للأطفال لتلبية متغير ات العصر ممـا يُستدعى ضـرورة إعداد بر امج للتنميـة المهنيـة للمشرفات التربويـات لا ثر اء بيئات التعليم و التعلم ومساعدتهم على تتمية قدر اتهن للتمكن من أداء أدور ها بكفاءة وجودة عالية. و تكوين مجتمعات تعلم مهنية فاعلة قادرة على احداث تغيير ببيئة التعلم بالروضة وتحقيق نواتج التعلم

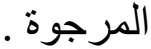

\section{أهداف اقامة مجتمعات التعلم المهنية لمشرفات رياض الأطفال:}

تتعدد الاهداف التي ينثدها مجتمع التعلم المهني وتتنوع من مجتمع مهني لأخر، ومن بيئة لأخرى ، وتختلف كذلك في مجتمع التعلم ذاته ،فكلما حقق مجتمع التعلم اهدافه تطلع الى اهداف اخرى جديدة اكثر طموحاوقد اشار (عمرو صالح بوزيد :11 ( إ) الى ان مجتمعات التعلم المهنية تهدف الى: 1 - بناء مجتمع تعلم متعاون بهدف التعليم و التعلم و التطوير بما يدعم التكامل r- - دمج طر ائق التعليم والتعلم r- تشجيع التفكير الناقد و الإبداعي في العملية التعليمية ع ـ تقليل التوتر المهني 0ـ الاداء المهني الافضل ونموه مدى الحياة 7ـ استخدام امثل للتقنيات الرقمية بما يتيح لا محدودية الخبرة و العولمة 
Vـ تشكيل وتفعيل النشاطات المعرفية ضمن دورة المعرفة ^ـ تفعيل وحدة التدريب و التقويم في التنمية المهنية المستدامة لجميع العاملين في بوزارة التربية

$$
9 \text { ـ الاهنمام بالتعلم الذاتي القائم على الخبر ات الفردية . }
$$

• ـ ـ الاهتمام بتدريب المعلمات وتأهيلهن وفقا للمستجدات التعليمية و الاتجاهات الحديثة

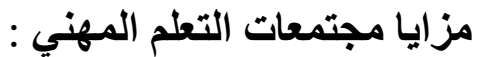

لم تعد المؤسسات التعليمية قادرة على مسايرة التغير ات و التحديات المتسـار عة، و اصبح و اقعها لا يـتلاءم مـع متطلبـات الحاضـر و المسـتقبل ،فز ادت الفجـوة بـين الو اقع و المـأمول ، ومـن هنـا جـاء مـدخل مجتمعات التعلم المهنية ليسهم في تحول المدارس من نمطها التقليدي الى مجتمع تعلم يسـاهم في التحسين و التقدم

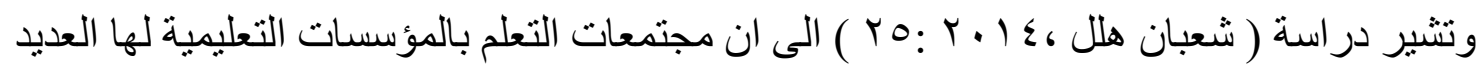

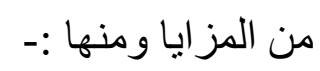

تمنح كل المشرفين و المعلمين والاباء و المتعلمين و اعضاء المجتمع المدرسي فرصة للمشاركة في

$$
\text { صنع القرار }
$$

تستثر مواردها البشرية في جميع المستويات الادارية بأقصى طاقة ممكنة تتشر المعرفة بين افر ادووحدات المؤسسة التعليمية زيادة الرضا الوظيفي و المهني لدى المعلمات استخدام تكنولوجيا التعلم وتطبيقاتها الحديثة في النواحي التعليمية والإشر اقية از الة الحو اجز بين فريق العمل والعمل بروح الفريق و الاسلوب التعاوني التعرف على الاتجاهات الحديثة في التربية وتطبيقاتها و الاستفادة بها تتمية قدر ات المعلمات على البحث و التجريب و التعلم الذاتي القائم على الخبر ات الفردية

و اذا كانت هذه المميز ات تظهر من انشاء مجتمعات التعلم المهنية فأنها تتو افر في ظل قيادة حكيمه (المشرفة التربوية ( تمتلك من المعـارف و الخبر ات و الكفايـات مـا يجعلها تقود هذا المجتمع وتقدم الدعم الفني و التربوي مما يرفع من كفائه المعلمات . 
كما تُعتبر المناقشات التي تتم بين المشرفات والمعلمـات ذات آتثار إيجابيـة لعملية التنمية المهنية فالتعاون و الشر اكة بين المشرفات و المعلمات في مجال مجتمعات التعلم المهنية يحقق أداء أفضل وبمرور الوقت يؤدي إلى رفع كفاءتهن المهنية و على وجه الخصوص المعلمات الجُدد و اللاتي يلتحقن بالعمل حديثًا

و عرف زافاتيسكي (Zavadsky, H. 2012:11) مجتمعات التعلم المهنية للمشرفات التربويـات بانها مجتمعات تشاركية مخططة مستمرة لتطوير أداء المعلمات تُلبي الحاجات المستمرة و المتغيرة لتعليم الأطفال وتحقيق الأهداف العامة لمرحلة رياض الأطفال.

وتشير در اسة (Andrews, M. 2013) بعنو ان دور مجتمعات التعلم التنمية المهنية القائم عليها المشرفات التربويات و اثار ها في تحسين الأداء المهني لمعلمات الطفولة المبكرة و التي هدفت الدر اسة إلى فحص العلاقة بين مجتمعات التعلم المهني القائم عليها المثرفات و اثر هـا على الأداء المهني لمعلمـات الطفولة المبكرة، توصلت إلى وجود علاقة ارتباط ذات دلالة إحصائية عند مستوى 0 ., · بين استجابات أفر اد العينة على أسئلة الاستبانة ومعايير التعليم الفعال بمرحلة رياض الأطفال، كما أظهرت علاقة ارتباط موجبة لأفر اد العينـة للتنميـة المهنيـة المستدامة وتحسين الأداء المهني لمعلمـات ريـاض الأطفـال من قبـل الدعم الموجه من المشرفات

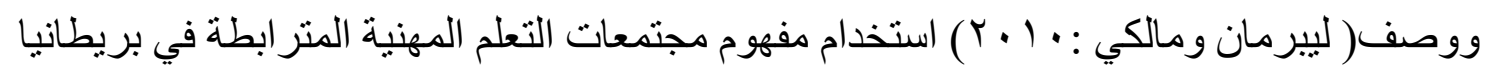
كأساس لتحسين طبيعة التنمية المهنية المستدامة للمعلمات .

و عند البحث عن رؤية متطلبـات مجتمعات التعلم المهنيـة لمشرفات ريـاض الأطفال تبرز مسـئل نو عية ومنهجية تتصل بأهمية مجتمعات التعلم المهنية و آليات العمل به، وبالاتجاهات المعاصرة و النمـاذج الإشر اقية المستجدة التي تنو عت وتتكّلت بحسب تنوع المعارف، وتدفق المعلومات المعرفية و التكنولوجيا وتغيير ات النظم التربوية ، ان العالم يمر بتغير ات سريعة ومذهلة في كافة المجلات المعرفية والتكنولوجية

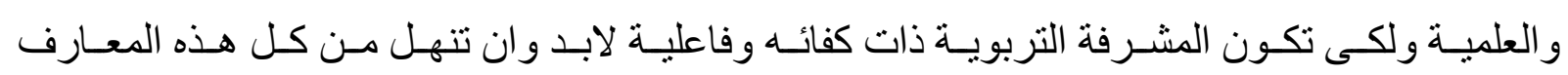
و المستجدات التربوية والاتجاهات التربوية الحديثة حتى تكون متجددة وفاعلة و على قدر كبير من الثقة بالنفس ،قادرة على الاجابة على تساؤ لات و استفسار ات المعلمات ،قادرة على تقييمهح وتقييم الاطفال قادرة على تقديم خدمة ذات جودة عاليـة للمؤسسـة التربويـة التي تتنمسى اليها وقادرة على اقامسه مجتمعـات تعلم مهني حقيقية ترفع من كفائه المعلمات وتوجههم دائما الى التنمية المهنية المستدامة . 
ومما تقدم من نتائج البحث نوجز أهم متطلبات اقامة مجتمعات التعلم المهني للمشرفات برياض الأطفال

ا - تشجيع المشرفات برياض الأطفال على التنميه المهنية دن خـلال الزيار ات الميدانيـة داخل وخارج مصر ، وتبادل الخبر ات و الأجتماعات وفقا لخطة سنوية تحدد من بداية العام الدر اسى .

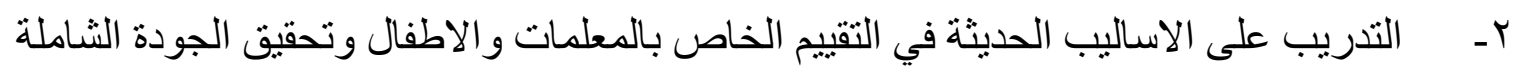

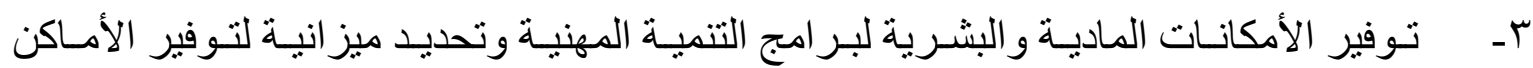
التدربية والوسائل التكنولوجية والأدوات اللأزمة للتدريب على البر امج.

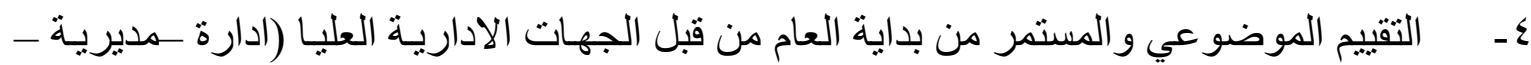
وزارة ) لتحديد الاحتياجات التدريبة للنمو المهنى للمشرفات برياض الأطفال.

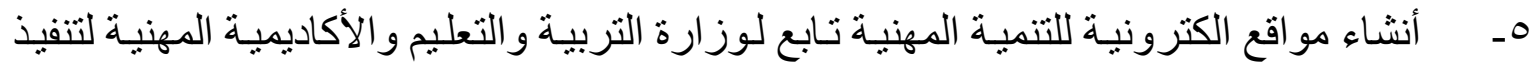

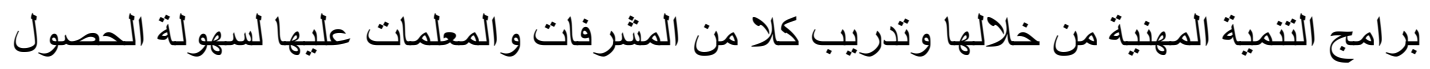
على المعلومات ،و النشر ات التوجيهية وايضا تفعيل الاشر اف الإلكتروني مني وني 7- التخطيط و التدريب لبر امج التنمية المهنية و التحول الرقمي للمشرفات و التي يكونوا على قدر من التخصص و الخبرة لتحقيق الاستفادة من التدريب. V- تدريب المشرفات على الطرق التكنولوجيا الحديثة في الاجتماعات و التو اصل كي يستخدموها مع المعلمات

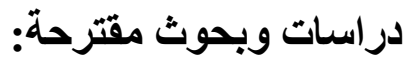

1 - برنامج تدريبي لمشرفات رياض الأطفال لتتمية أساليب الاتصال و التو اصل محليا و إقليميا. r بـبرنامج تدريبي لتحسين أداء مشرفات رياض الأطفال فى نظم المتابعة و التقويم.

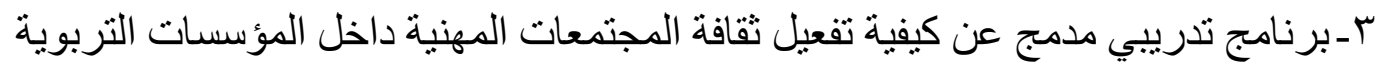
ع ـ برنامج تدريبي مدمج لمشرفات رياض الاطفال حول التحول الرقمي و أهميته 


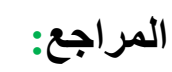

أولاً: المراجع العربية:

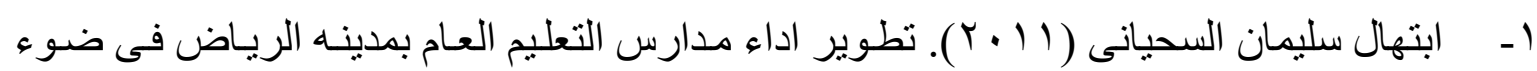

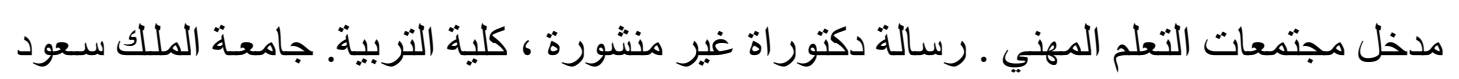

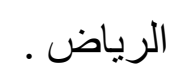

r- أبو عمرو إسـحاق بن مـرار الثيبياني، معجم الجيم، تحقيق: إبر اهيم الإبياري، الهيئة العامـة

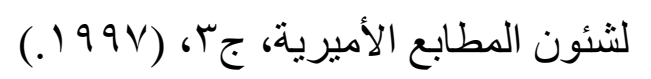

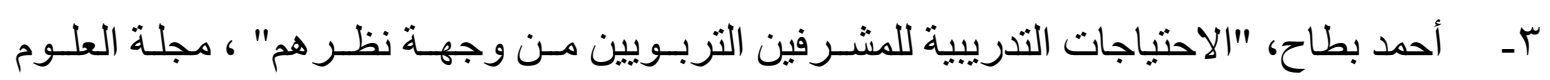

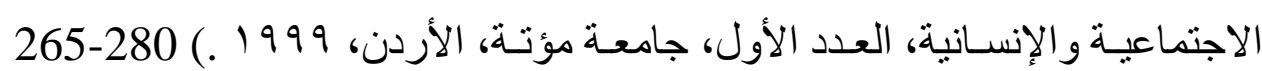

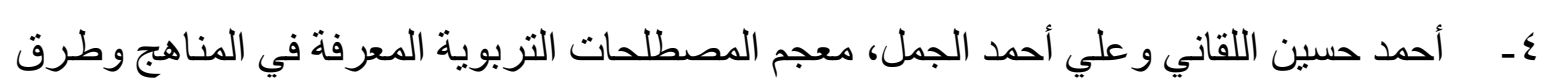

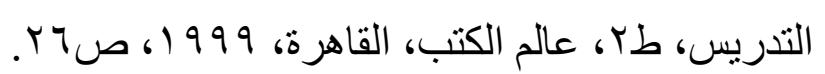

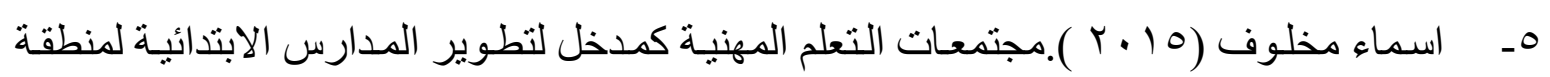
جاز ان فى ضوء نموذج اوليفر هب وهو فمان ،مجلة التربية، ب (170 ( ) ) .

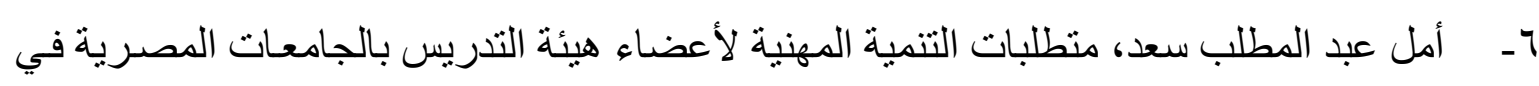

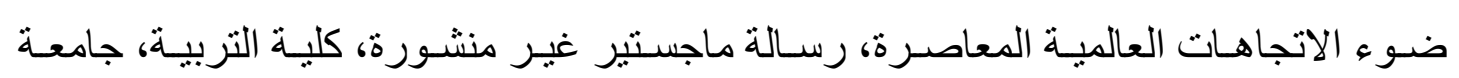

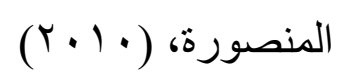

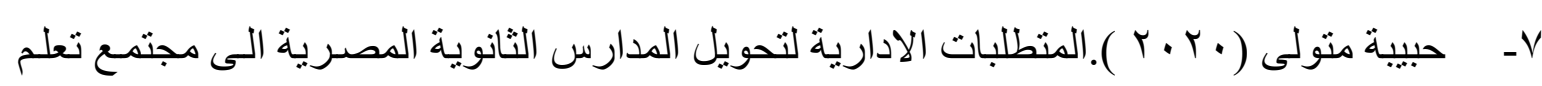

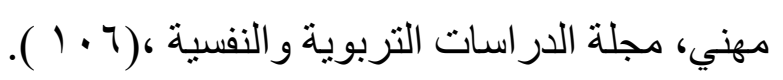

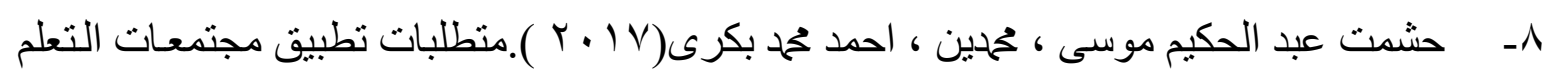

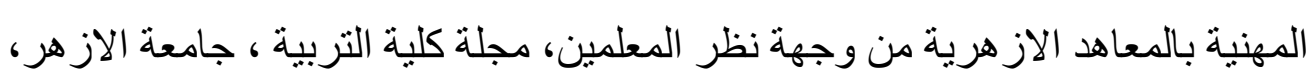

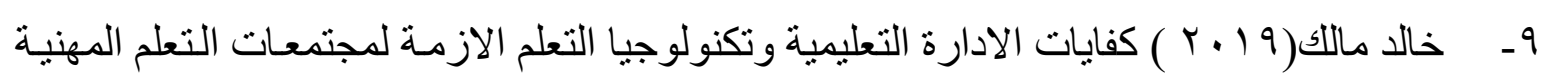
فى ظل مهار ات القرن الواحد و العشرين و الثورة الصناعية الر ابعة ،مجلة كلية التربية، (؟ ؟ )

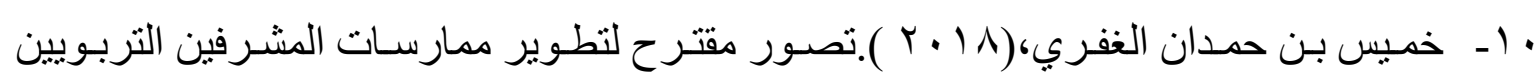

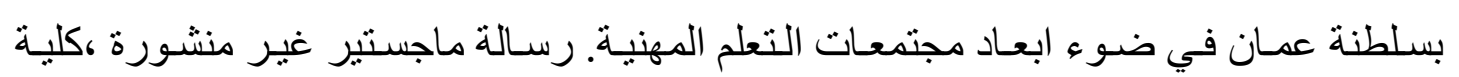
التربية=جامعة السلطان قابوس .

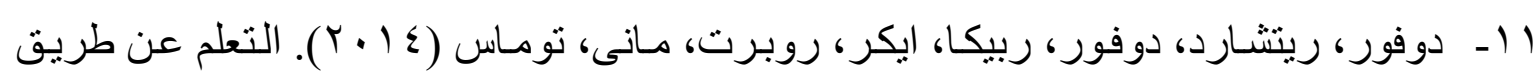

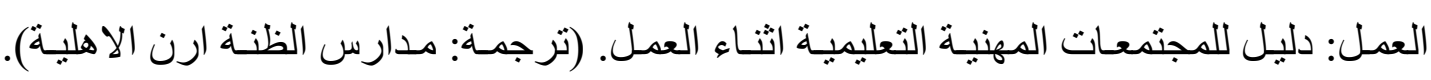
الدمام دار الكتاب التربوي 


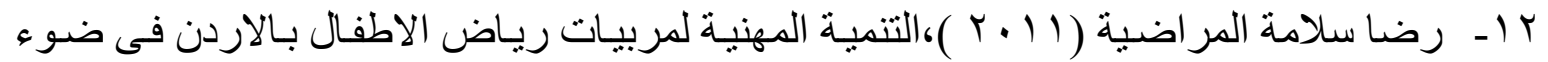
معابير الجودة تصور مقترح ، رسالة ماجستير غير منشورة ، معهد الدراسات التربوية، جامعـة القاهرة س ا ـ سالم تحمد سليم العلواني، التنميـة المهنية لمعلمي التربية الخاصـة بالمملكة العربيـة السعودية في ضوء خبرات بعض الدول، رسالة دكتور اه غير منشورة، كلية البنات، جامعة عين شمس، ـ ا ـ سعيد جاسم الاسدي ومروان عبدالمجيد إبر اهيم: الإشراف التربوي، دار الثقافة للنشر و التوزيع،

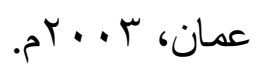

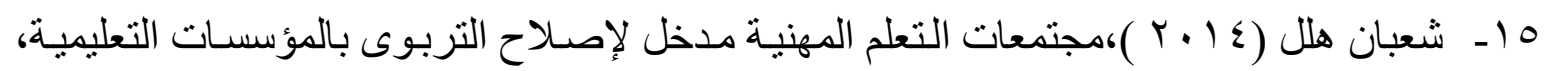
مصر :مكتبة بستان المعرفة .

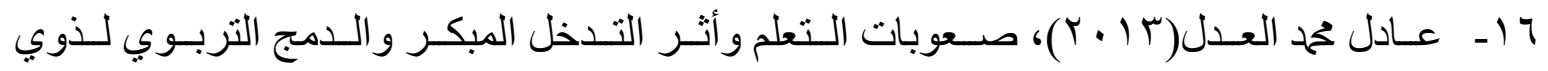
الاحتياجات الخاصة، القاهرة، دار الكتاب الحديث.

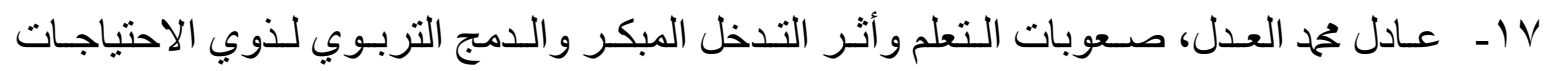
الخاصة، القاهرة، دار الكتاب الحديث، ب ا ـ ب ب. 1 ا - ـعبد الكريم محمود القاسم، الاحتجاجات التدريبية للمهار ات الإشر افية كما بتصور ها المشرفون التربويون في مديريات التربية والتعليم في محافظات شمال فلسطين، مجلة علوم إنسـانية ،السنة

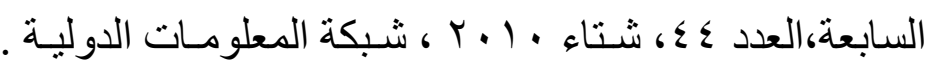
9 ا ـ عبد الله بن عو اد الحربى (Y Y (Y).دور الاشر اف التربوي في تحقيق متطلبـات مجتمع المعرفة فى محافظة حفر الباطن -المؤتمر الثاني و العشرون للجمعية المصرية للمناهج وطرق التدريس بعنوان "مناهج التعليم في مجتمع المعرفة ،مصر . • ـ ـ عزة جلال مصطفى، آليات التنمية المهنية لمديري مدارس التعليم قبل الجامعي، المركز القومي

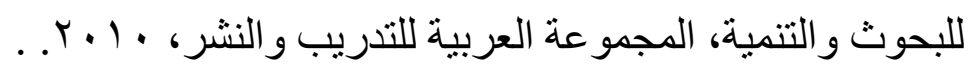

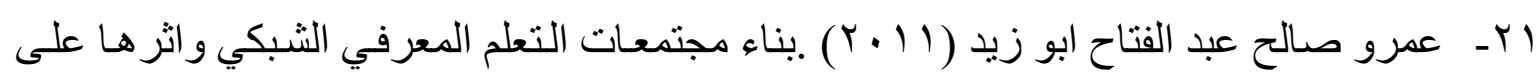
معلمي العلوم .مجلة كلية التربية-جامعة الفيوم،( ( ) ، ( )

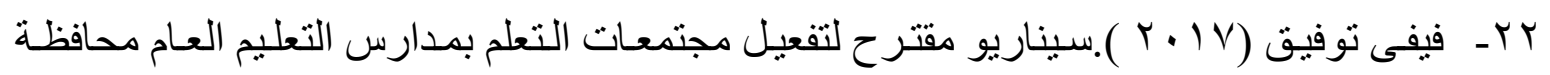

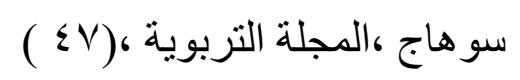

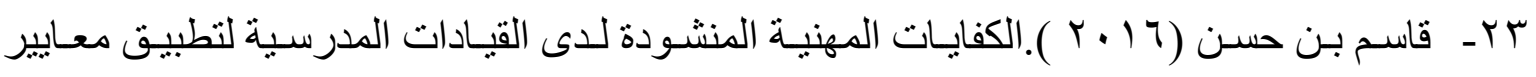
مجتمعـات الـتعلم المهنيـة بمؤسسـات التعلـيم العـام بالسـعودية :نمـوذج مقتـرح ،مجلـة التقافـة

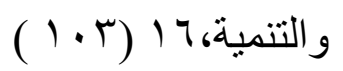




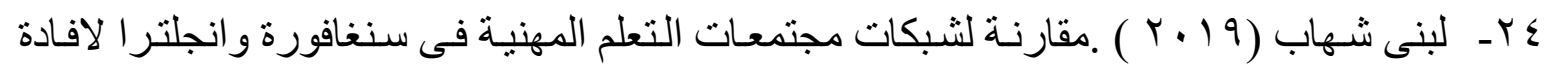

منها فى المدارس المصرية ، المجلة التربوية ، (70)

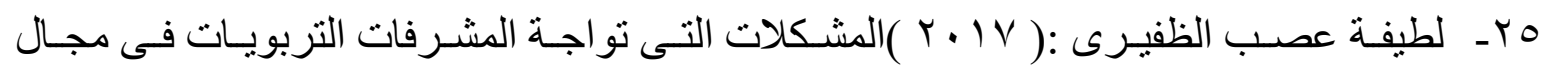

التدريب اثتاء الخدمة بمحافظة عفيف، مجلة عالم التربية ،المؤسسة العربيـة لاستشـار ات العلميـة

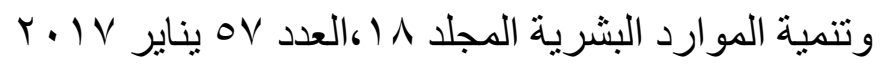

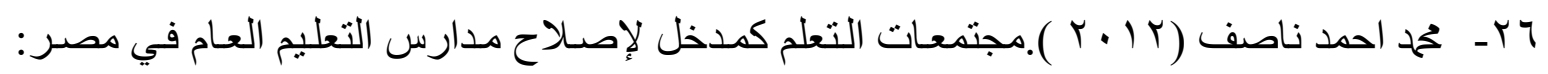

در اسة تحليلية مجلة كلية التربية، جامعة طنطا،(ی ؟ )

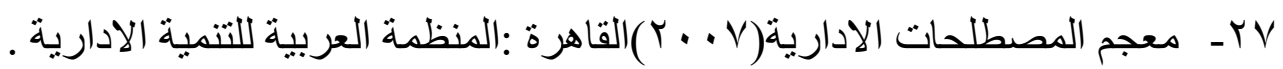

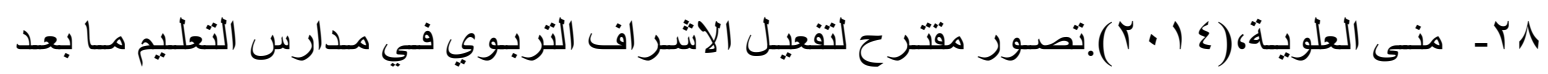

الأساسـي بمحافظـة مسقط في ضـوء نموذج الاشر اف المتنوع .رسـالة ماجستير كليـة التربيـة،

جامعة نزوى ،سلطنة عمان.

\section{ثانياً: المراحع الاجنبية:}

29- Ambrosetti, Angelina (2012). "The Impact Of Preparing Mentor Teachers For Mentoring Using Continuous Professional Development". AsiaPacific Journal of Teacher Education, 33(1), 53-64

30- Anderson, S.E. (2011). Continuous Professional Development for Kindergarten and Primary Teachers and Supervisors According to Quality Standards. Upper Saddle River NJ: Merrill Prentice Hall.

31- Andrews, M. (2013). "Understanding the Mentoring Experience: The Role of Sustainable Professional Development of Mentors (SPD) in Improving Early Childhood Education Profession". British Journal of Social Work.

32- Bakan, I. (2013). An Investigation of Organizational commitment and education level among employees. Information Journal of Emerging Sciences. 1 (3).

33- Beach, D. B., \& Reinhartz, J. (2014). Supervisory leadership: Focus on instruction. Toronto, ON: Allyn and Bacon. 
34- Bell Les and Day Chirs, Managing the Professional Development of Teacher Buckingham, Open University, U.S.A., 1999, P. 54.

35- Burgess, Robert G. and Others, Implementing In-service Education and Training Bristo, Falmer Press, 1993, P. 137.

36- -Course, A. (2010). Developing personal learning networks for open and social learning. In G. Veletsianos (Ed.), Emerging technologies in distance education (pp. 109e128). Edmonton, Canada: Athabasca University Press

37- Davis Brent \& Ellison Lina, School Leadership for the 21 st Century, Rout Leugc, London, 1998.

38- Fisher, J. O. (2009). Quality Control In Education: The Teacher Factor. In T. E. Ajayi and J. Fadipe (eds) Skills improvement programme for effective performance of teachers in Nigerian schools. A publication of National Institute for Educational Planning and Administration (NIEPA), Ondo. 128

39- Heberman, martin, The Dimensions of Excellence in Programs of Teacher Education Paper Presened at the Annual Conference South Padre, Texas, 2008.

40- Herzenberg, S. (2011). Losing Ground In Early Childhood Education: Declining Workforce Qualifications In An Expanding Industry, 19792004. Washington, DC: Economic Policy Institute.

41- Lord, Pippa; Atkinson, Mary; Mitchell, Holly (2011). Mentoring And Coaching For Early Childhood Professionals: A Study Of The Research Evidence For Continuous Professional Development. National Foundation for Educational Research: TDA.

42- Mitchell, L. and Cubey, P. (2011) Characteristics Of Effective Professional Development Linked To Enhanced Pedagogy And Children's Learning In Early Childhood Settings: Best Evidence Synthesis. Wellington, NZ: Ministry of Education 
43- Nolan, Andrea; Morrissey, Anne-Marie; Beahan, Jenni; Dumenden, Iris (2011). "Pilot Sustainable Professional Development Mentoring Program for Early Childhood Teachers". Department of Education and Early Childhood Development, Deakin University.

44- Rice, Rosalind. "The Theory And Practice Of Continuous Professional Development of Kindergarten Mentors/Facilitators: Is There A Dichotomy In The Role Of Learning Theories?" Paper presented at the British Educational Research Association Annual Conference, University of Warwick, 6-9 September, 2014

45- Thomas, Jordan (2013). Mentoring Beginning Teachers: Programs of Continuous Professional Development to Improve Mentors' Performance. Holmes Group, East Lansing, MI.

46- Zavadsky, H. (2012). Bringing School Reform To Scale: Five AwardWinning Urban D Rice, Rosalind. "The Theory And Practice Of Continuous Professional Development of Kindergarten Mentors/Facilitators: Is There A Dichotomy In The Role Of Learning Theories?" Paper presented at the British Educational Research Association Annual Conference, University of Warwick, 6-9 September, 2014. 


\section{الملاحق}

ملحق رقم 1 استبانة المشرفات

\begin{tabular}{|c|c|c|c|c|}
\hline دائما & احيانا & نادرا & 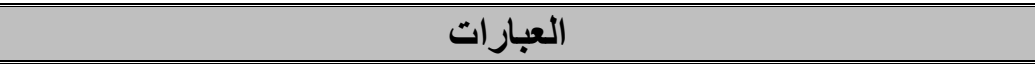 & م \\
\hline & & & 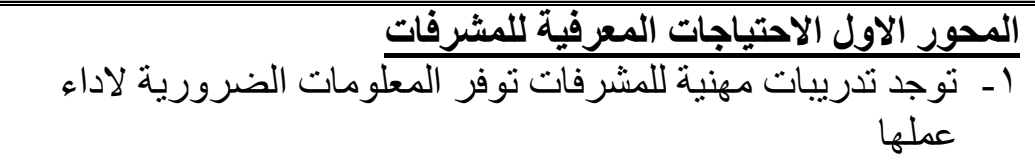 & 1 \\
\hline & & & r- تتمى لديها المفاهيم الخاصة بمجال رياض الأطفال & \\
\hline & & & rا - تعرف استر اتيجيات التعليم الحديثة برياض الاطفال & \\
\hline & & & ــ ـ تخطط لتفعيل مشاركات مؤسسات المجتمع المحلى مع الروضة & \\
\hline & & & 0ـ تعرف الجديد فى مجال تقييم الاداء للمعلمة & \\
\hline & & & 7- يتعرف على اخر المستجدات فى مناهج رياض الأطفال & \\
\hline & & & V- ت تتدرب على استر اتيجيات حل المشكلات & \\
\hline & & & 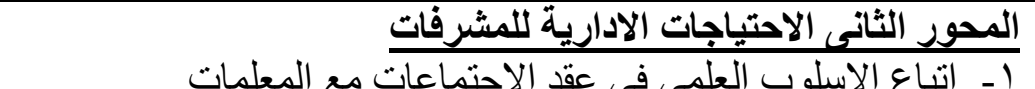 & t \\
\hline & & & r - التخطيط للزيار ات الميدانية للروضات & \\
\hline & & & r- التخطيط للتنمية المهنية الذاتية & \\
\hline & & & ــ ـ التخطيط للتنمية المهنية لمعلمة الروضة & \\
\hline & & & 0ـ الاشر اف على الدور ات التدريبية القصيرة(فنيا واداريا) & \\
\hline & & & 7ـ الاشر اف على تتفيذ الخطط التعليمية للوزارة & \\
\hline & & & 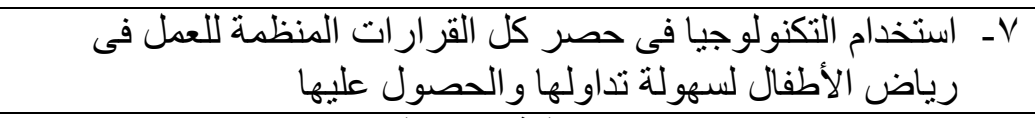 & \\
\hline & & & 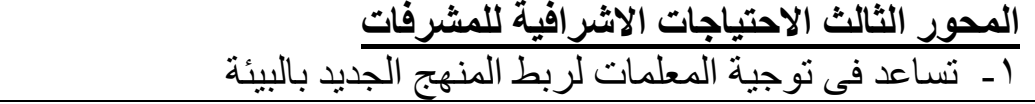 & $r$ \\
\hline & & & r- مشاركة المعلمات فى اعداد وتطوير رساله الروضة & \\
\hline & & & r- مشاركة المعلمات فى تخطيط البر امج الاسبو عية و الثهرية و السنوية & \\
\hline & & & ــ اتباع الاسلوب العلمى فى عقد الاجتماعات مع المعلمات & \\
\hline & & & 0ـ استخدام اسـاليب وطرق تتاسب الاهداف الموضو عية للبر امج اليومية & \\
\hline & & & 7ـ التخطيط الفعال لاشر اف التربوى & \\
\hline & & & V- استخدام الاساليب المناسبة لاشر اف التربوى & \\
\hline
\end{tabular}

